\title{
LEVEL II SCOUR ANALYSIS FOR BRIDGE 30 (ROYATH00060030) on TOWN HIGHWAY 6, crossing the WHITE RIVER, ROYALTON, VERMONT
}

Open-File Report 98-264

Prepared in cooperation with

VERMONT AGENCY OF TRANSPORTATION

and

FEDERAL HIGHWAY ADMINISTRATION

U.S. Department of the Interior

U.S. Geological Survey

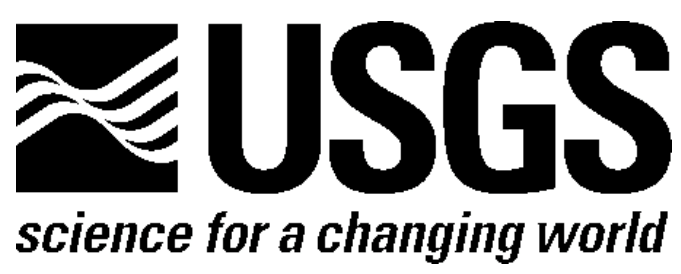




\section{LEVEL II SCOUR ANALYSIS FOR BRIDGE 30 (ROYATH00060030) on TOWN HIGHWAY 6, crossing the WHITE RIVER, ROYALTON, VERMONT}

By MICHAEL A. IVANOFF AND ROBERT E. HAMMOND

U.S. Geological Survey Open-File Report 98-264

Prepared in cooperation with

VERMONT AGENCY OF TRANSPORTATION

and

FEDERAL HIGHWAY ADMINISTRATION 


\title{
U.S. DEPARTMENT OF THE INTERIOR BRUCE BABBITT, Secretary
}

\author{
U.S. GEOLOGICAL SURVEY
}

Thomas J. Casadevall, Acting Director

For additional information write to:

District Chief

U.S. Geological Survey 361 Commerce Way

Pembroke, NH 03275-3718
Copies of this report may be purchased from:

U.S. Geological Survey

Branch of Information Services

Open-File Reports Unit

Box 25286

Denver, CO 80225-0286 


\section{CONTENTS}

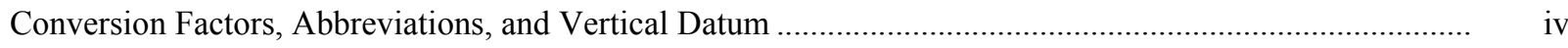

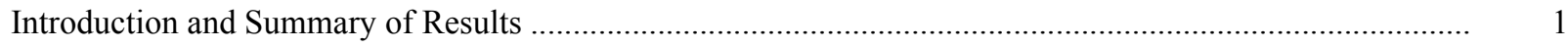

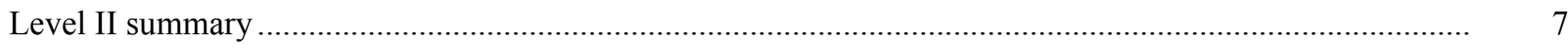

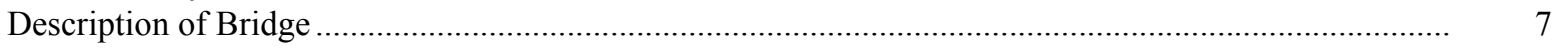

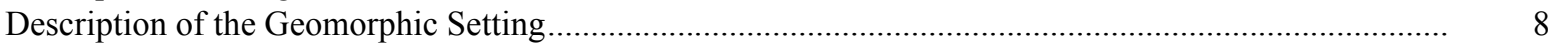

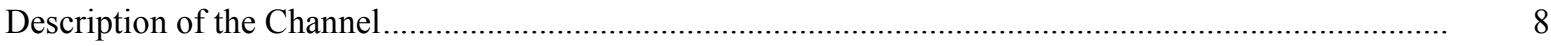

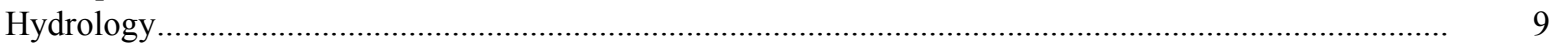

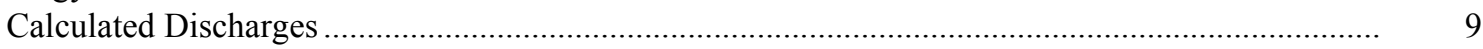

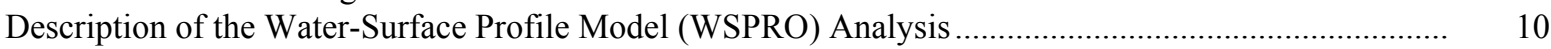

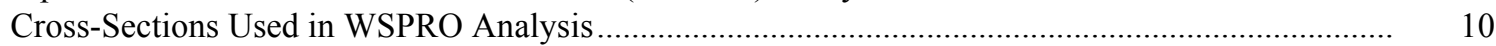

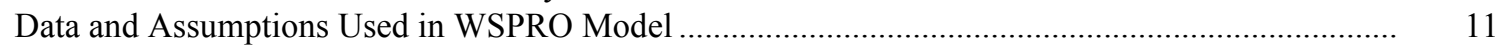

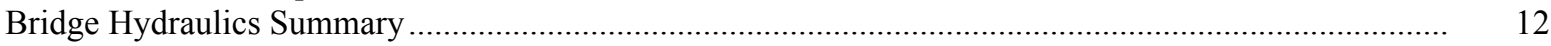

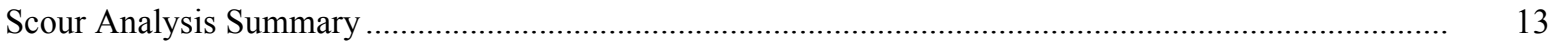

Special Conditions or Assumptions Made in Scour Analysis ..................................................... 13

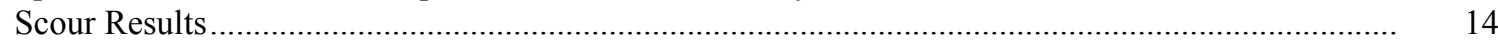

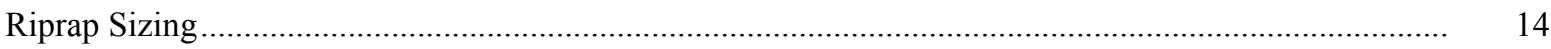

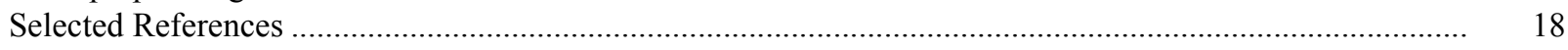

Appendices:

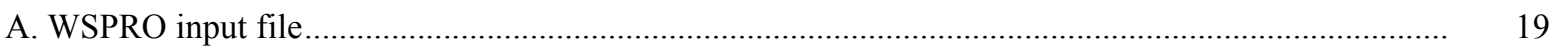

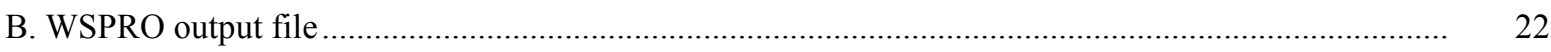

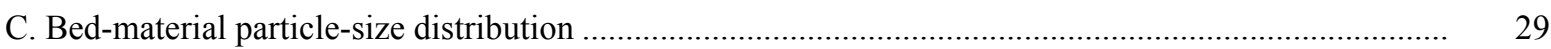

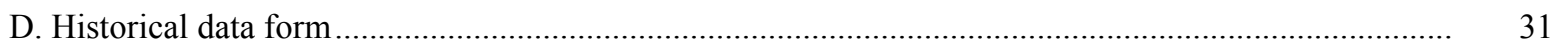

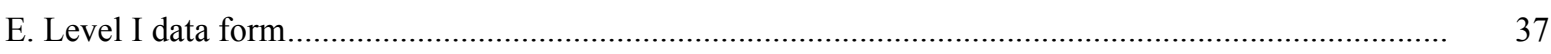

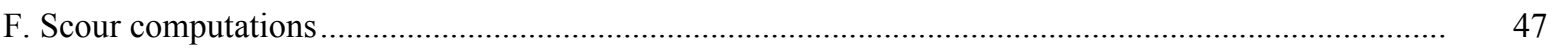

\section{FIGURES}

1. Map showing location of study area on USGS 1:24,000 scale map

2. Map showing location of study area on Vermont Agency of Transportation town

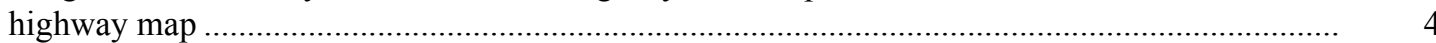

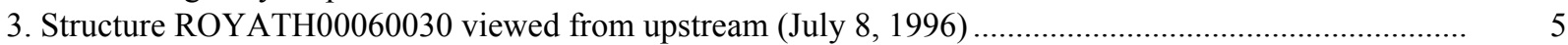

4. Downstream channel viewed from structure ROYATH00060030 (July 8, 1996). ................................. 5

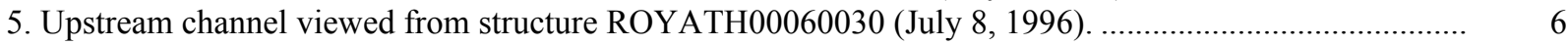

6. Structure ROYATH00060030 viewed from downstream (July 8, 1996)............................................. 6

7. Water-surface profiles for the 100- and 500-year discharges at structure

ROYATH00060030 on Town Highway 6, crossing the White River,

Royalton, Vermont.

8. Scour elevations for the 100- and 500-year discharges at structure

ROYATH00060030 on Town Highway 6, crossing the White River,

Royalton, Vermont.

\section{TABLES}

1. Remaining footing/pile depth at abutments for the 100-year discharge at structure

ROYATH00060030 on Town Highway 6, crossing the White River,

Royalton, Vermont.

2. Remaining footing/pile depth at abutments for the 500-year discharge at structure

ROYATH00060030 on Town Highway 6, crossing the White River,

Royalton, Vermont. 


\begin{tabular}{|c|c|c|}
\hline Multiply & By & To obtain \\
\hline \multicolumn{3}{|c|}{ Length } \\
\hline inch (in.) & 25.4 & millimeter (mm) \\
\hline foot $(\mathrm{ft})$ & 0.3048 & $\operatorname{meter}(\mathrm{m})$ \\
\hline mile (mi) & 1.609 & kilometer (km) \\
\hline \multicolumn{3}{|c|}{ Slope } \\
\hline foot per mile ( $\mathrm{ft} / \mathrm{mi})$ & 0.1894 & meter per kilometer $(\mathrm{m} / \mathrm{km})$ \\
\hline \multicolumn{3}{|c|}{ Area } \\
\hline square mile $\left(\mathrm{mi}^{2}\right)$ & 2.590 & square kilometer $\left(\mathrm{km}^{2}\right)$ \\
\hline \multicolumn{3}{|c|}{ Volume } \\
\hline cubic foot $\left(\mathrm{ft}^{3}\right)$ & $\begin{array}{l}0.02832 \\
\text { Velocity and Flow }\end{array}$ & cubic meter $\left(\mathrm{m}^{3}\right)$ \\
\hline foot per second $(\mathrm{ft} / \mathrm{s})$ & 0.3048 & meter per second $(\mathrm{m} / \mathrm{s})$ \\
\hline cubic foot per second $\left(\mathrm{ft}^{3} / \mathrm{s}\right)$ & 0.02832 & cubic meter per second $\left(\mathrm{m}^{3} / \mathrm{s}\right)$ \\
\hline $\begin{array}{l}\text { cubic foot per second per } \\
\text { square mile } \\
{\left[\left(\mathrm{ft}^{3} / \mathrm{s}\right) / \mathrm{mi}^{2}\right]}\end{array}$ & 0.01093 & $\begin{array}{l}\text { cubic meter per } \\
\text { second per square } \\
\text { kilometer }\left[\left(\mathrm{m}^{3} / \mathrm{s}\right) / \mathrm{km}^{2}\right]\end{array}$ \\
\hline
\end{tabular}

\section{OTHER ABBREVIATIONS}

\begin{tabular}{|c|c|c|c|}
\hline $\mathrm{BF}$ & bank full & LWW & left wingwall \\
\hline $\mathrm{cfs}$ & cubic feet per second & Max & maximum \\
\hline $\mathrm{D}_{50}$ & median diameter of bed material & $\mathrm{MC}$ & main channel \\
\hline DS & downstream & RAB & right abutment \\
\hline elev. & elevation & RABUT & face of right abutment \\
\hline $\mathrm{f} / \mathrm{p}$ & flood plain & $\mathrm{RB}$ & right bank \\
\hline $\mathrm{ft}^{2}$ & square feet & ROB & right overbank \\
\hline $\mathrm{ft} / \mathrm{ft}$ & feet per foot & RWW & right wingwall \\
\hline FEMA & Federal Emergency Management Agency & $\mathrm{TH}$ & town highway \\
\hline FHWA & Federal Highway Administration & UB & under bridge \\
\hline JCT & junction & US & upstream \\
\hline LAB & left abutment & USGS & United States Geological Survey \\
\hline LABUT & face of left abutment & VTAOT & Vermont Agency of Transportation \\
\hline LB & left bank & WSPRO & water-surface profile model \\
\hline LOB & left overbank & $\mathrm{yr}$ & year \\
\hline
\end{tabular}

In this report, the words "right" and "left" refer to directions that would be reported by an observer facing downstream. Sea level: In this report, "sea level" refers to the National Geodetic Vertical Datum of 1929-- a geodetic datum derived from a general adjustment of the first-order level nets of the United States and Canada, formerly called Sea Level Datum of 1929.

In the appendices, the above abbreviations may be combined. For example, USLB would represent upstream left bank. 


\title{
LEVEL II SCOUR ANALYSIS FOR BRIDGE 30 (ROYATH00060030) ON TOWN HIGHWAY 6, CROSSING THE WHITE RIVER, ROYALTON, VERMONT
}

\author{
By Michael A. Ivanoff and Robert E. Hammond
}

\section{INTRODUCTION AND SUMMARY OF RESULTS}

This report provides the results of a detailed Level II analysis of scour potential at structure ROYATH00060030 on Town Highway 6 crossing the White River, Royalton, Vermont (figures 1-8). A Level II study is a basic engineering analysis of the site, including a quantitative analysis of stream stability and scour (Federal Highway Administration, 1993). Results of a Level I scour investigation also are included in appendix E of this report. A Level I investigation provides a qualitative geomorphic characterization of the study site. Information on the bridge, gleaned from Vermont Agency of Transportation (VTAOT) files, was compiled prior to conducting Level I and Level II analyses and is found in appendix D.

The site is in the New England Upland section of the New England physiographic province in central Vermont. The $479-\mathrm{mi}^{2}$ drainage area is in a predominantly rural and forested basin. In the vicinity of the study site, the surface cover on the right bank is pasture and on the left bank there is shrub and brush while the immediate banks have dense woody vegetation.

In the study area, the White River has an incised, meandering channel with a slope of approximately $0.003 \mathrm{ft} / \mathrm{ft}$, an average channel top width of $308 \mathrm{ft}$ and an average bank height of $15 \mathrm{ft}$. The channel bed material ranges from gravel to cobble with a median grain size $\left(\mathrm{D}_{50}\right)$ of $68.3 \mathrm{~mm}(0.224 \mathrm{ft})$. The geomorphic assessment at the time of the Level I and Level II site visit on July 8, 1996, indicated that the reach was stable.

The Town Highway 6 crossing of the White River is a 165-ft-long, two-lane bridge consisting of one 159-foot steel thru-truss span (Vermont Agency of Transportation, written communication, May 24, 1995). The opening length of the structure parallel to the bridge face is $161 \mathrm{ft}$. The bridge is supported by vertical, concrete abutments with wingwalls only on the right bank. The channel is skewed approximately 10 degrees to the opening while the opening-skew-to-roadway is zero degrees. 
A scour hole $12 \mathrm{ft}$ deeper than the mean thalweg depth was observed in the channel along the left bank upstream of bridge during the Level I assessment. A second scour hole $5 \mathrm{ft}$ deeper than the mean thalweg is just downstream of the bridge along the left bank. The scour protection measures at the site included type- 2 stone fill (less than 36 inches diameter) along the upstream right wingwall and type-3 stone fill (less than 48 inches diameter) along the downstream right wingwall. There are also stacked concrete bags along the base of the footing on the left and right abutments. Additional details describing conditions at the site are included in the Level II Summary and appendices D and E.

Scour depths and recommended rock rip-rap sizes were computed using the general guidelines described in Hydraulic Engineering Circular 18 (Richardson and others, 1995) for the 100- and 500-year discharges. In addition, the incipient roadway-overtopping discharge was determined and analyzed as potential worst-case scour scenario. Total scour at a highway crossing is comprised of three components: 1) long-term streambed degradation; 2) contraction scour (due to accelerated flow caused by a reduction in flow area at a bridge) and; 3) local scour (caused by accelerated flow around piers and abutments). Total scour is the sum of the three components. Equations are available to compute depths for contraction and local scour and a summary of the results of these computations follows.

Contraction scour for all modelled flows ranged from 0.0 to $3.3 \mathrm{ft}$. The worst-case contraction scour occurred at the incipient roadway-overtopping discharge. Left abutment scour ranged from 38.5 to $41.2 \mathrm{ft}$. The worst-case left abutment scour occurred at the 500year discharge, however, the left abutment footing is on a ledge outcrop which may limit the scour depth. Right abutment scour ranged from 11.2 to $28.1 \mathrm{ft}$. The worst-case right abutment scour occurred at the incipient roadway-overtopping discharge. Additional information on scour depths and depths to armoring are included in the section titled "Scour Results". Scoured-streambed elevations, based on the calculated scour depths, are presented in tables 1 and 2. A cross-section of the scour computed at the bridge is presented in figure 8. Scour depths were calculated assuming an infinite depth of erosive material and a homogeneous particle-size distribution.

It is generally accepted that the Froehlich equation (abutment scour) gives "excessively conservative estimates of scour depths" (Richardson and others, 1995, p. 47). Usually, computed scour depths are evaluated in combination with other information including (but not limited to) historical performance during flood events, the geomorphic stability assessment, existing scour protection measures, and the results of the hydraulic analyses. Therefore, scour depths adopted by VTAOT may differ from the computed values documented herein. 


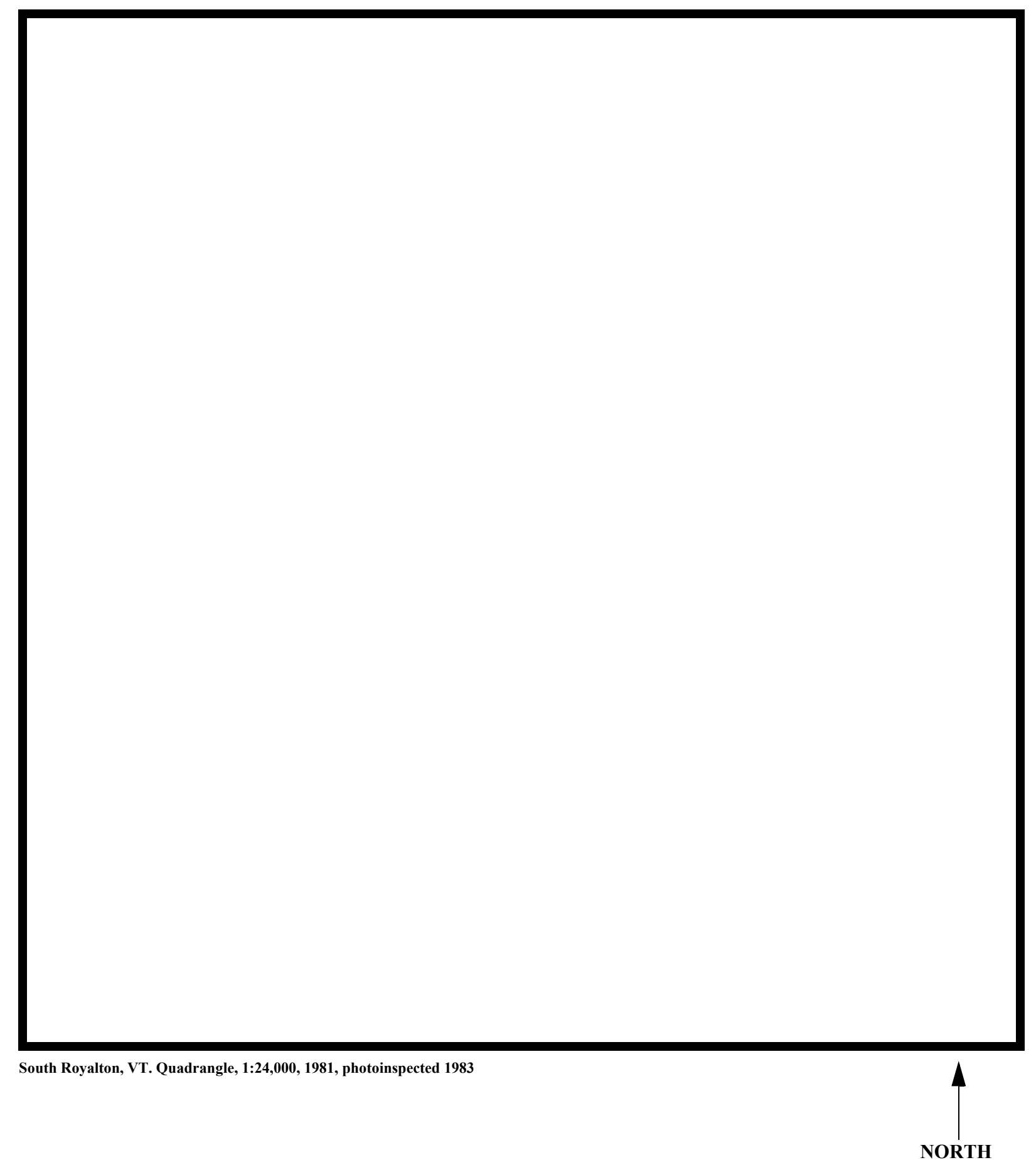

Figure 1. Location of study area on USGS 1:24,000 scale map. 
Figure 2. Location of study area on Vermont Agency of Transportation town highway map. 

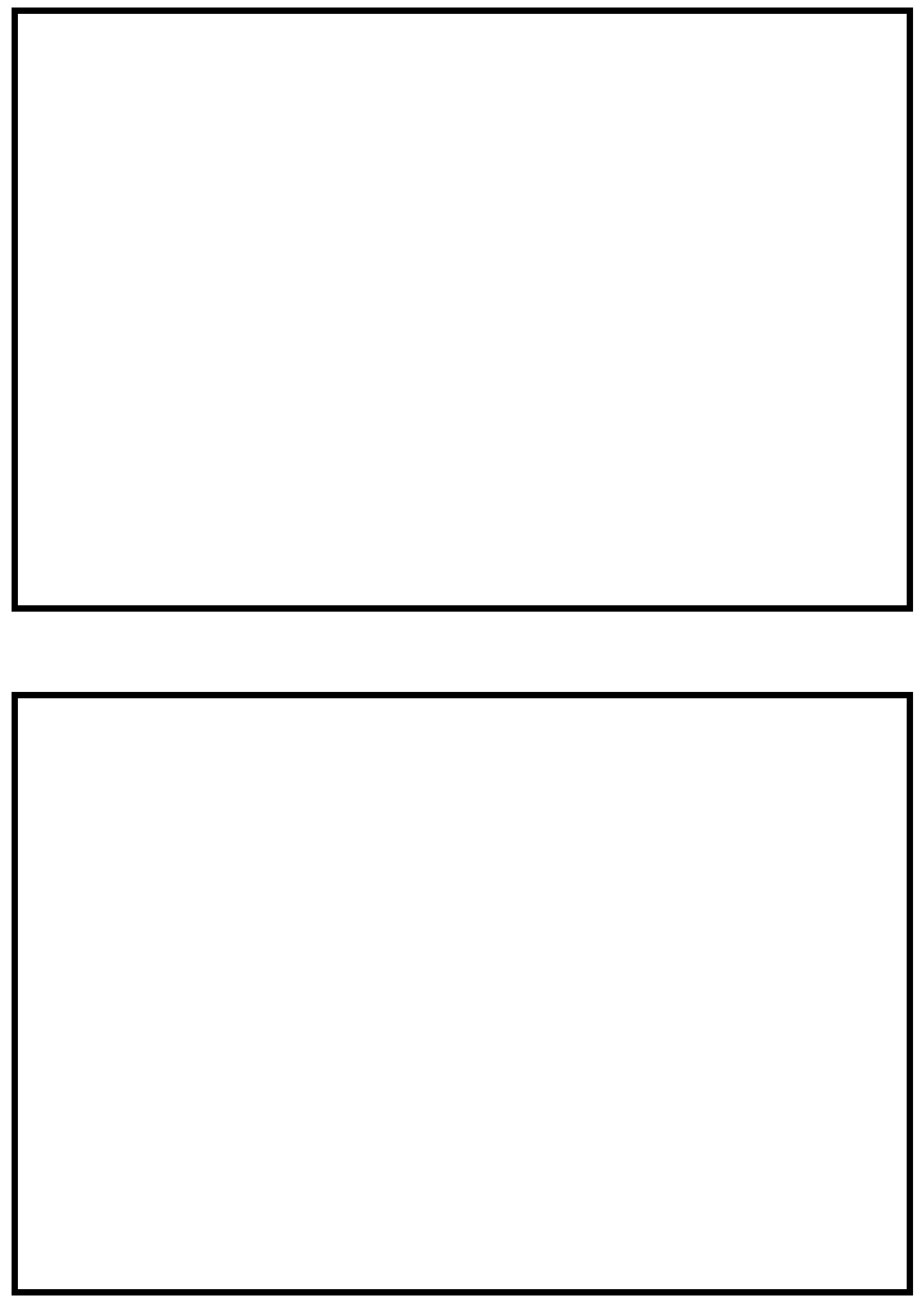

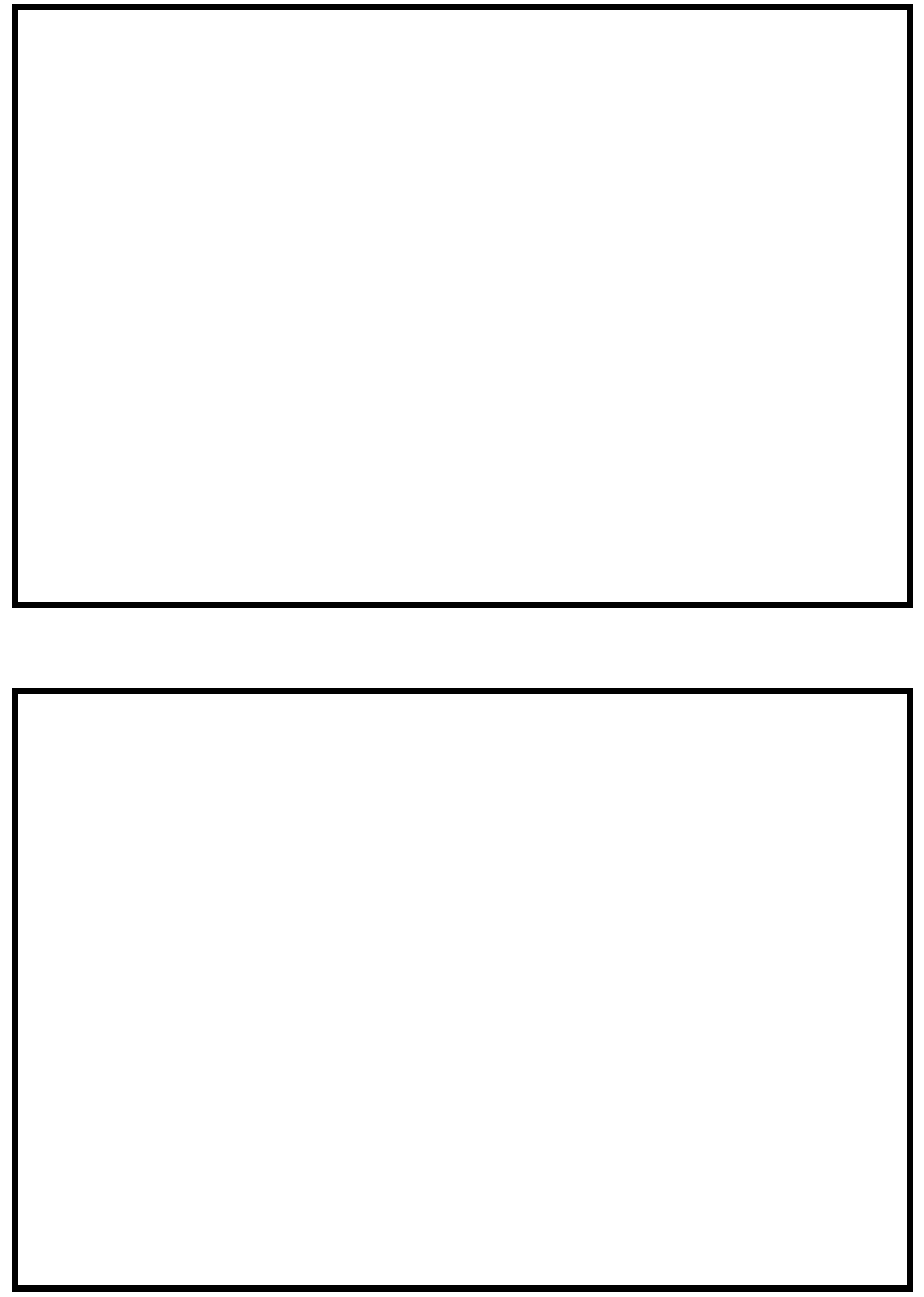


\section{LEVEL II SUMMARY}

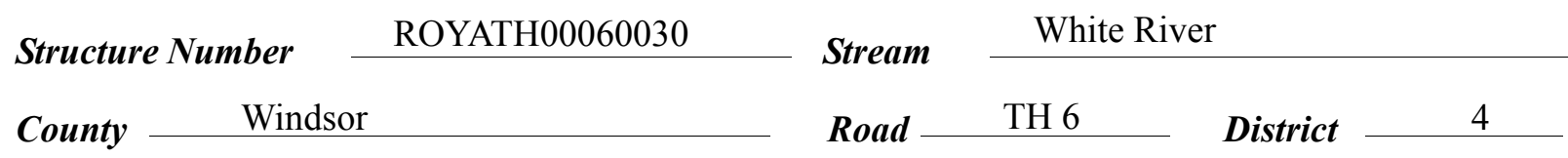

\section{Description of Bridge}

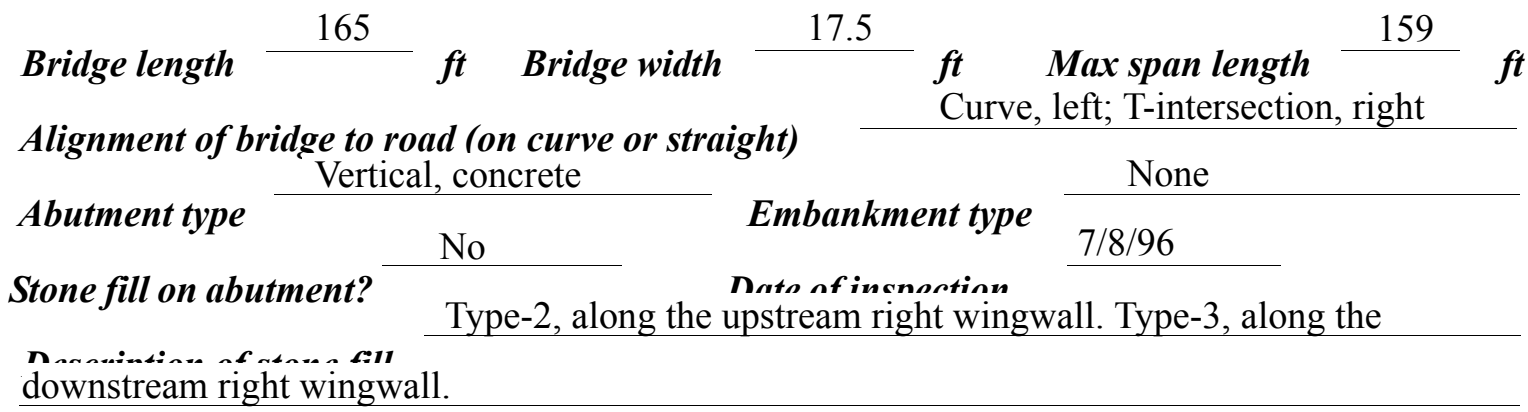

Abutments and wingwalls on the right abutment are

concrete. There are large concrete filled bags at the base of the left and right abutment footings.

There is a $12 \mathrm{ft}$ deep scour hole upstream of the bridge along the left bank.

Yes

Is bridge skewed to flood flow according to No ' survey?

Angle

There is a moderate channel bend in the upstream reach

Debris accumulation on bridge at time of Level I or Level II site visit:

\begin{tabular}{|c|c|c|}
\hline $\begin{array}{l}\text { Date of incnortion } \\
7 / 8 / 96 \\
\end{array}$ & $\begin{array}{l}\text { Percent of ohmunal } \\
\text { blocked nortzontatly }\end{array}$ & $\begin{array}{l}\text { Percent of } 0 \\
\text { blocked verticatty }\end{array}$ \\
\hline 7/8/96 & 0 & 0 \\
\hline
\end{tabular}

Low. There are trees leaning over the channel upstream.

Potential for debris

A large ledge outcrop in the channel along the upstream left bank forms an eddy current resulting Doscriho anv foaturos noar ar at tho hridoo that mav affort flow, (includo ahsorvation datol in a significant scour hole as of 7/8/96. There is an additional ledge outcrop and scour hole

downstream. 


\section{Description of the Geomorphic Setting}

General topography The channel is located within a moderate relief valley with flat to slightly irregular narrow flood plain with steep valley walls on both sides.

Geomorphic conditions at bridge site: downstream (DS), upstream (US)

Date of inspection $\quad 7 / 8 / 96$

DS left: $\quad$ Moderately sloped channel bank to the overbank.

DS right: $\quad$ Steep channel bank to a narrow flood plain.

US left: $\quad$ Moderately sloped channel bank to the overbank.

US right: $\quad$ Moderately sloped channel bank to a narrow flood plain.

\section{Description of the Channel}

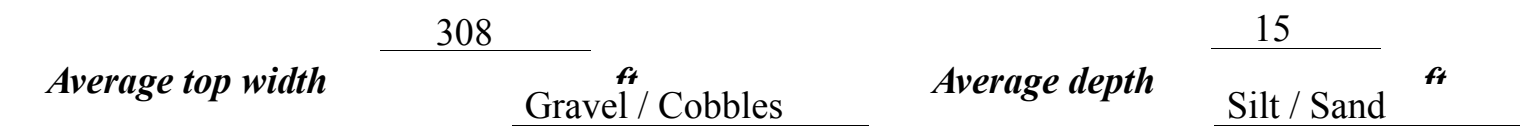

Predominant bed material Bank material Meandering but

stable with semi-allüvial channel boundaries and a narrow floo $\ddot{\text { p plain. }}$

Vegetative col $^{\text {Short grass brush with a few trees. } \quad \ldots \quad \ldots \quad .} \frac{7 / 8 / 96}{}$

DS left: $\quad$ Trees and brush with pasture on the flood plain.

DS right: $\quad$ Short grass and brush with a few trees.

US left: $\quad$ Trees and brush with pasture on the flood plain.

US right: $\quad$ Yes

Do banks appear stable? -

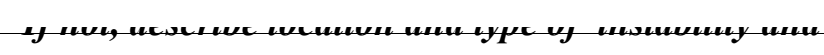

date of observatton.

None, 7/8/96.

Describe any obstructions in channel and date of observation. 


\title{
Hydrology
}

Drainage area $\quad 479 \boldsymbol{m i}^{2}$

Percentage of drainage area in physiographic provinces: (approximate)

Physiographic province/section New England/New England Upland
Percent of drainage area 100

\begin{abstract}
Is drainage area considered rural or urban?
Rural urbanization:

Describe any significant
\end{abstract}

Yes

Is there a USGS gage on the stream of interest? White River at West Hartford, VT USGS gage description 01144000

USGS gage number 690

Gage drainage area $\quad \mathrm{mi}^{2}$ No

Is there a lake/p -

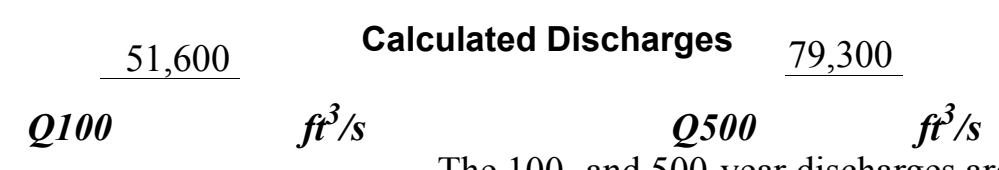

The 100- and 500-year discharges are based on a

drainage area relationship [(479/690/exp 0.67] with the gage (01144000) on the White River at West Hartford, VT. The drainage area adjusted discharges are within a range of several flood frequency curves based on empirical methods (Benson, 1962; Johnson and Tasker, 1974;

FHWA, 1983; Potter, 1957a\&b; Talbot, 1887). 


\section{Description of the Water-Surface Profile Model (WSPRO) Analysis}

Datum for WSPRO analysis (USGS survey, sea level, VTAOT plans) ～USGS survey

Datum tie between USGS survey and VTAOT plans $\quad$ Subtract $404 \mathrm{ft}$ from the USGS arbitrary

survey datum to obtain VTAOT plans' datum.

Description of reference marks used to determine USGS datum. $\quad$ RM1 is a chiseled X on

top of the DS end of the right abutment bridge seat (elev. $502.57 \mathrm{ft}$, arbitrary survey datum).

RM2 is a chiseled X on top of the US end of the left abutment at the road surface elevation (elev.

$506.37 \mathrm{ft}$, arbitrary survey datum). RM3 is a chiseled $\mathrm{X}$ in a chiseled square in the bedrock on

the left bank US at the bottom of a wooden staircase

(elev. $491.14 \mathrm{ft}$, arbitrary survey datum).

\section{Cross-Sections Used in WSPRO Analysis}

\begin{tabular}{cccl}
\hline${ }^{1}$ Cross-section & $\begin{array}{c}\text { Section } \\
\text { Reference } \\
\text { Distance } \\
\text { (SRD) } \text { in feet }\end{array}$ & $\begin{array}{c}{ }^{2} \text { Cross-section } \\
\text { development }\end{array}$ & \multicolumn{1}{c}{ Comments } \\
\hline EXITX & -119 & 1 & Exit section \\
FULLV & 0 & 2 & $\begin{array}{l}\text { Downstream Full-valley } \\
\text { section (Templated from } \\
\text { EXITX) }\end{array}$ \\
BRIDG & 0 & 1 & $\begin{array}{l}\text { Bridge section } \\
\text { RDWAY }\end{array}$ \\
APPRO & 15 & 1 & Road Grade section \\
\hline
\end{tabular}

${ }^{1}$ For location of cross-sections see plan-view sketch included with Level I field form, Appendix E.

For more detail on how cross-sections were developed see WSPRO input file.

2 Cross-section development: (1) survey at SRD, (2) shift of survey data to SRD, (3) modification of survey data,

(4) composite bridge section, (5) other. 


\section{Data and Assumptions Used in WSPRO Model}

Hydraulic analyses of the reach were done by use of the Federal Highway Administration's WSPRO step-backwater computer program (Shearman and others, 1986, and Shearman, 1990). The analyses reported herein reflect conditions existing at the site at the time of the study. Furthermore, in the development of the model it was necessary to assume no accumulation of debris or ice at the site. Results of the hydraulic model are presented in the Bridge Hydraulic Summary, appendix B, and figure 7.

Channel roughness factors (Manning's “ $n$ ”) used in the hydraulic model were estimated using field inspections at each cross section following the general guidelines described by Arcement and Schneider (1989). Final adjustments to the values were made during the modelling of the reach. Channel " $\mathrm{n}$ " values for the reach ranged from 0.040 to 0.060 , and overbank " $\mathrm{n}$ " values ranged from 0.050 to 0.080 .

Normal depth at the exit section (EXITX) was assumed as the starting water surface. This depth was computed by use of the slope-conveyance method outlined in the user's manual for WSPRO (Shearman, 1990). The slope used was $0.0027 \mathrm{ft} / \mathrm{ft}$, which was estimated from the water surface profile for the 100-year event downstream of the site in the Flood Insurance Study for Royalton, VT (Federal Emergency Management Agency, 1989).

The approach section (APPRO) was surveyed one bridge length upstream of the upstream face as recommended by Shearman and others (1986). This location provides a consistent method for determining scour variables. 


\section{Bridge Hydraulics Summary}

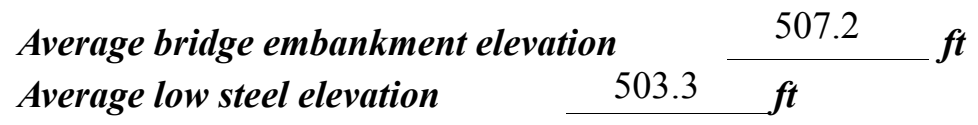

$$
\text { 100-year discharge } \quad 51,610 \quad \mathrm{ft}^{3} / \mathrm{s}
$$

Water-surface elevation in bridge opening $\quad 500.0 \mathrm{ft}$

Road overtopping? ___ Yes Discharge over road __ 14,430 $\mathrm{ft}^{3} / \mathrm{s}$

Area of flow in bridge opening $\quad 3,250 \quad \mathrm{ft}^{2}$

Average velocity in bridge opening $11.4 \quad \mathrm{ft} / \mathrm{s}$

Maximum WSPRO tube velocity at bridge $13.5 \mathrm{ft} / \mathrm{s}$

Water-surface elevation at Approach section with bridge $\quad 502.9$

$\begin{array}{ll}\text { Water-surface elevation at Approach section without bridge } & 501.0\end{array}$

Amount of backwater caused by bridge $\quad 1.9$ it

500-year discharge $\quad 79,320 \quad \mathrm{ft}^{3} / \mathrm{s}$

Water-surface elevation in bridge opening $\quad 503.4 \mathrm{ft}$

Road overtopping? ___ Yes Discharge over road _ $39,680 \mathrm{ft}^{3} / \mathbf{s}$

Area of flow in bridge opening $\quad 3,770 \quad \mathrm{ft}^{2}$

Average velocity in bridge opening $10.4 \mathrm{ft} / \mathrm{s}$

Maximum WSPRO tube velocity at bridge $12.0 \_$'s

Water-surface elevation at Approach section with bridge 505.9

Water-surface elevation at Approach section without bridge $\quad 504.1$

Amount of backwater caused by bridge $\quad 1.8, t$

Incipient overtopping discharge $\quad 38,490 \mathrm{ft}^{3} / \mathrm{s}$

Water-surface elevation in bridge opening $495.7 \quad t$

Area of flow in bridge opening $\quad 2,606 \quad \mathrm{ft}^{2}$

Average velocity in bridge opening $\quad 14.8 \quad \mathrm{ft} / \mathrm{s}$

Maximum WSPRO tube velocity at bridge $\quad 17.2 \mathrm{ft} / \mathrm{s}$

Water-surface elevation at Approach section with bridge

Water-surface elevation at Approach section without bridge

499.8

Amount of backwater caused by bridge $\quad 1.7_{\text {, t }}$

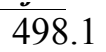




\section{Scour Analysis Summary}

\section{Special Conditions or Assumptions Made in Scour Analysis}

Scour depths were computed using the general guidelines described in Hydraulic Engineering Circular 18 (Richardson and others, 1995). Scour depths were calculated assuming an infinite depth of erosive material and a homogeneous particle-size distribution. However, bedrock was observed in contact with the left abutment. The results of the 100year and 500-year scour analysis are presented in tables 1 and 2 and a graph of the scour depths is presented in figure 8 .

Contraction scour for the 100-year and incipient roadway-overtopping discharges was computed by use of the Laursen clear-water contraction scour equation (Richardson and others, 1995, p. 32, equation 20). At this site, the 500-year discharge resulted in submerged orifice flow. Contraction scour at bridges with orifice flow is best estimated by use of the Chang pressure-flow scour equation (oral communication, J. Sterling Jones, October 4, 1996). Thus, contraction scour for this discharge was computed by use of the Chang equation (Richardson and others, 1995, p. 145-146). The contraction scour result for the 100 -year and 500-year discharges was zero ft.

For comparison, contraction scour for the 500-year discharge resulting in orifice flow was also computed by use of the Laursen clear-water contraction scour equation and the Umbrell pressure-flow equation (Richardson and others, 1995, p. 144) and presented in appendix F.

Abutment scour for the left abutment was computed by use of the Froehlich equation (Richardson and others, 1995, p. 48, equation 28). Variables for the Froehlich equation include the Froude number of the flow approaching the embankments, the length of the embankment blocking flow, and the depth of flow approaching the embankment less any roadway overtopping. The left abutment footing is on a ledge outcrop which may limit the scour depth.

Scour at the right abutment was computed by use of the HIRE equation (Richardson and others, 1995, p. 49, equation 29) because the HIRE equation is recommended when the length to depth ratio of the embankment blocking flow exceeds 25 . The variables used by the HIRE abutment-scour equation are defined the same as those defined for the Froehlich abutment-scour equation. 


\section{Scour Results}
100-yr discharge 500-yr discharge
Incipient overtopping (Scour depths in feet)

Contraction scour:

Main channel

Live-bed scour

Clear-water scour

Depth to armoring

Left overbank

Right overbank
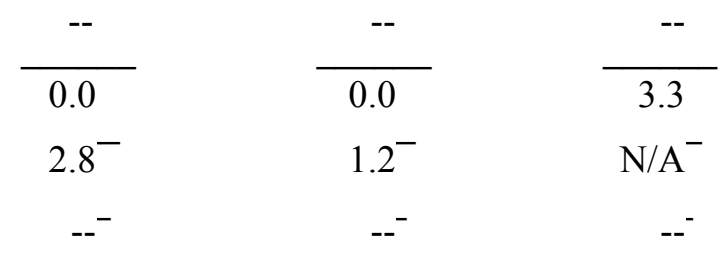

$\mathrm{N} / \mathrm{A}^{-}$

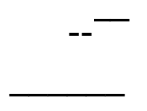

$--$
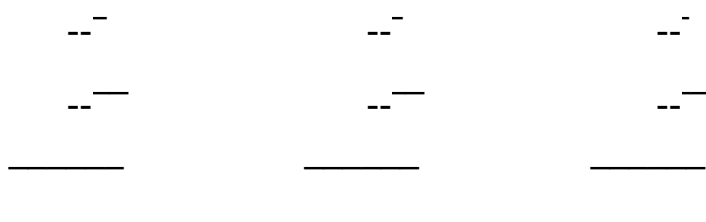

Local scour:

Abutment scour

Left abutment

38.6

41.2

38.5

11.2

$14.2-$

28.1-

\section{Right abutment}

Pier scour

Pier 1

Pier 2

Pier 3

Abutments:

Left abutment

Right abutment

Piers:

Pier 1

Pier 2

\section{Riprap Sizing}

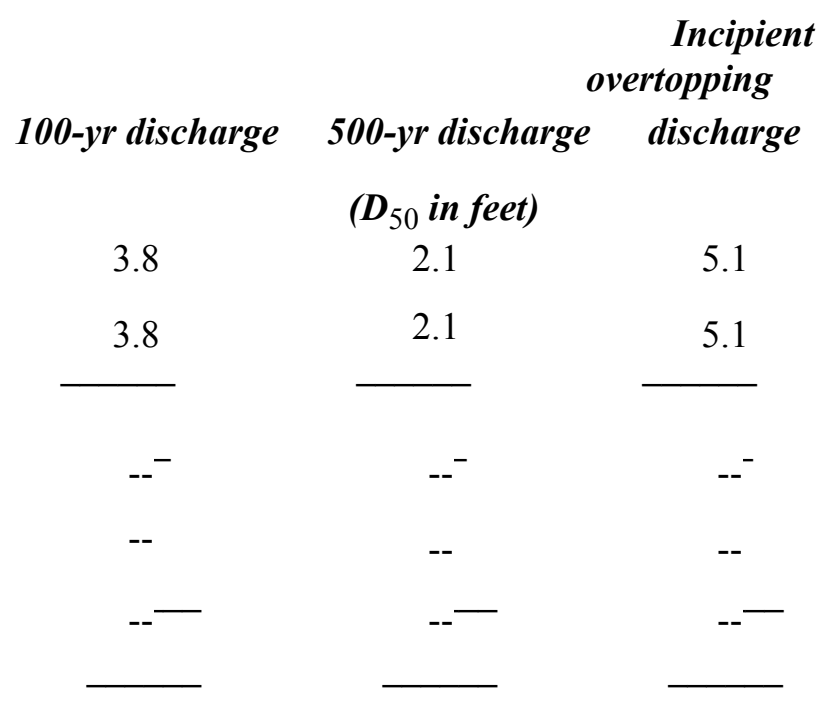




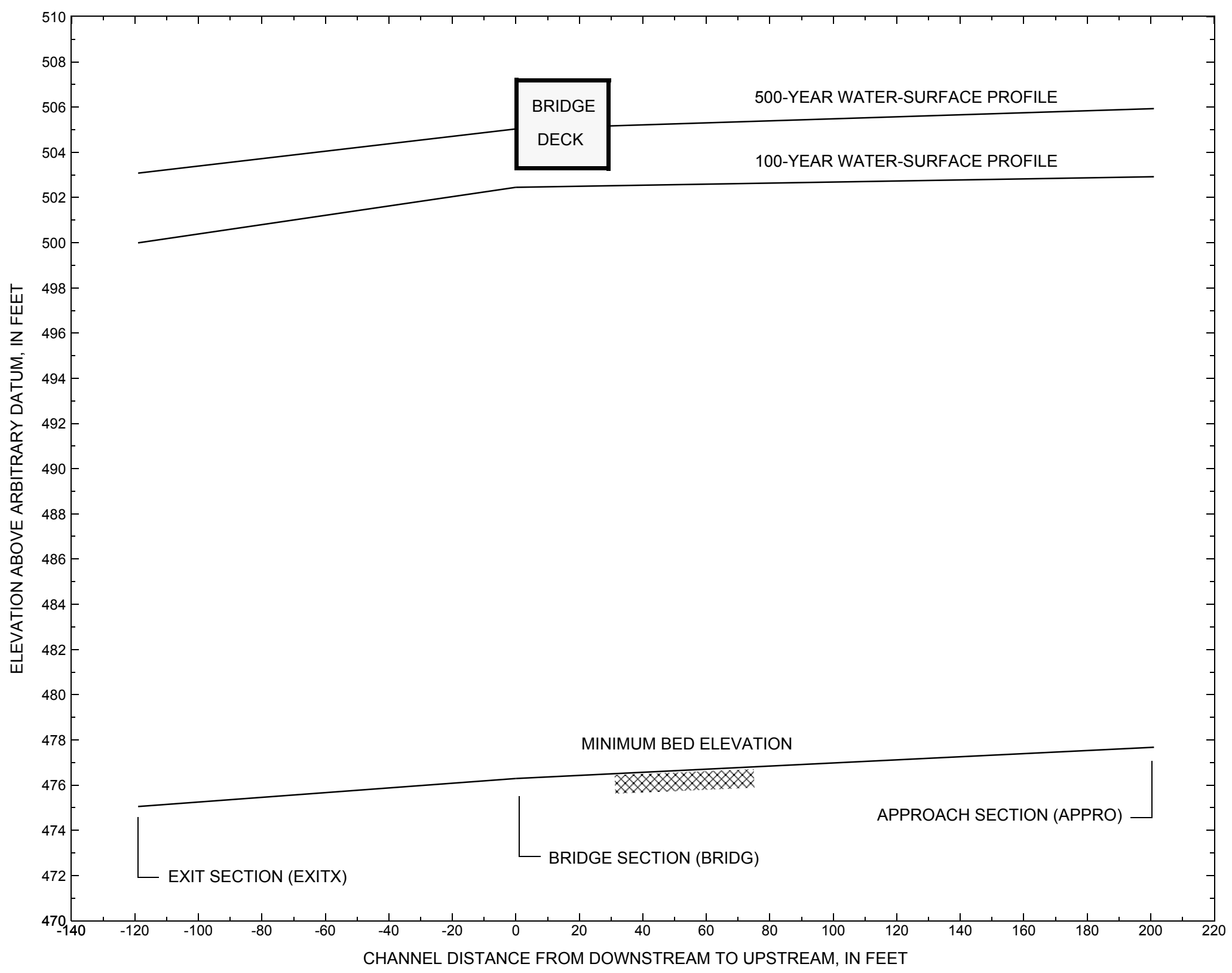

Figure 7. Water-surface profiles for the 100- and 500-year discharges at structure ROYATH00060030 on Town Highway 6, crossing the White River, Royalton, Vermont. 


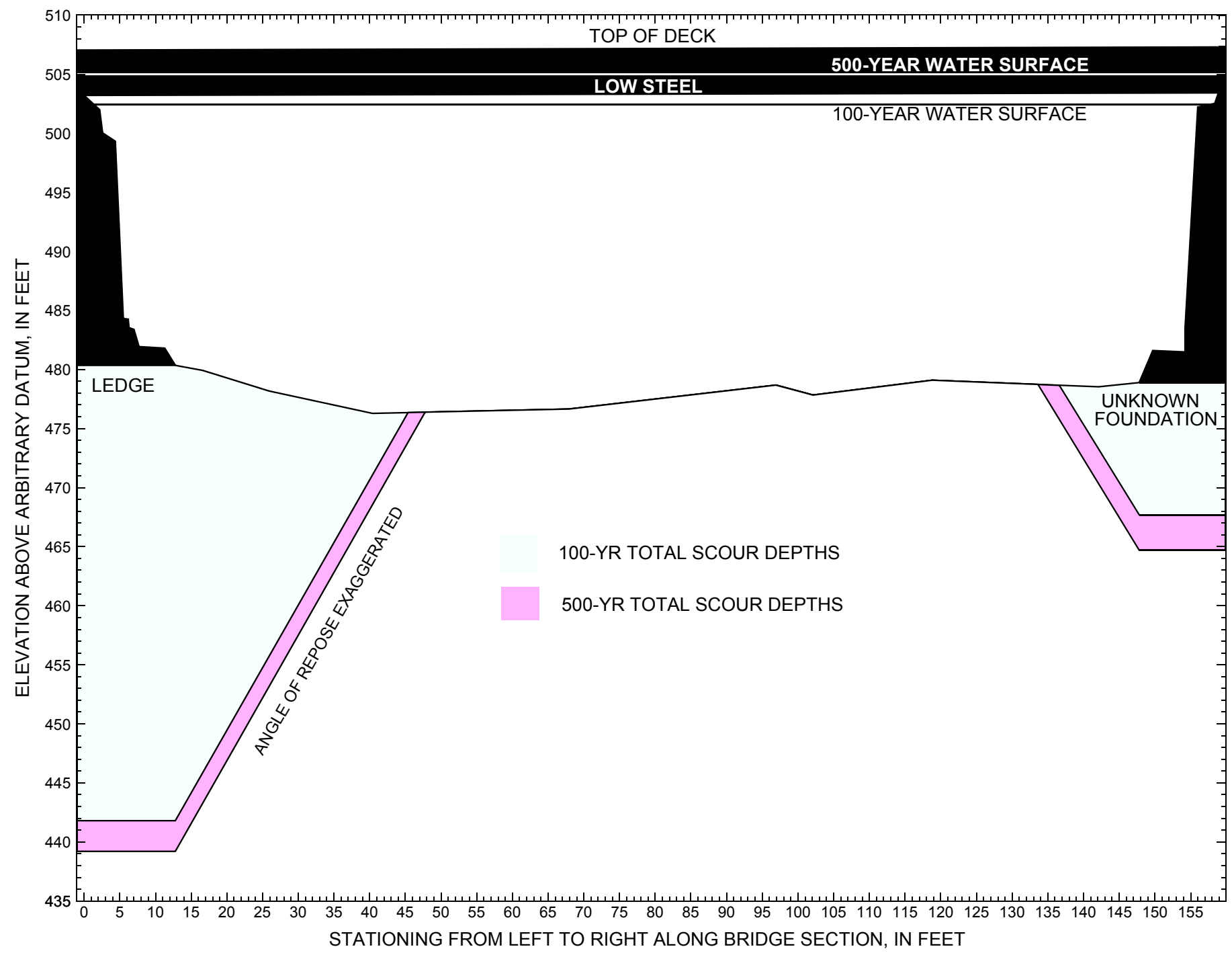

Figure 8. Scour elevations for the 100- and 500-year discharges at structure ROYATH00060030 on Town Highway 6, crossing the White River, Royalton, Vermont. 
Table 1. Remaining footing/pile depth at abutments for the 100-year discharge at structure ROYATH00060030 on Town Highway 6, crossing the White River, Royalton, Vermont.

[VTAOT, Vermont Agency of Transportation; --,no data]

\begin{tabular}{|c|c|c|c|c|c|c|c|c|c|c|c|}
\hline Description & Station $^{1}$ & $\begin{array}{l}\text { VTAOT } \\
\text { minimum } \\
\text { bridge seat } \\
\text { elevation } \\
\text { (feet) }\end{array}$ & $\begin{array}{l}\text { Surveyed } \\
\text { minimum } \\
\text { low-chord } \\
\text { elevation } \\
\text { (feet) }\end{array}$ & $\begin{array}{c}\text { Bottom of } \\
\text { footing/pile } \\
\text { elevation }{ }^{2} \\
\text { (feet) }\end{array}$ & $\begin{array}{l}\text { Channel } \\
\text { elevation at } \\
\text { abutment/ } \\
\text { pier }^{2} \\
\text { (feet) }\end{array}$ & $\begin{array}{l}\text { Contraction } \\
\text { scour depth } \\
\text { (feet) }\end{array}$ & $\begin{array}{l}\text { Abutment } \\
\text { scour } \\
\text { depth } \\
\text { (feet) }\end{array}$ & $\begin{array}{l}\text { Pier } \\
\text { scour } \\
\text { depth } \\
\text { (feet) }\end{array}$ & $\begin{array}{l}\text { Depth of } \\
\text { total scour } \\
\text { (feet) }\end{array}$ & $\begin{array}{c}\text { Elevation of } \\
\text { scour }^{2} \\
\text { (feet) }\end{array}$ & $\begin{array}{c}\text { Remaining } \\
\text { footing/pile } \\
\text { depth } \\
\text { (feet) }\end{array}$ \\
\hline \multicolumn{12}{|c|}{100 -year discharge is 51,610 cubic-feet per second } \\
\hline Left abutment & 0.0 & 97.9 & 503.2 & -- & 480.4 & 0.0 & 38.6 & -- & 38.6 & 441.8 & -- \\
\hline Right abutment & 158.9 & 98.2 & 503.4 & -- & 478.9 & 0.0 & 11.2 & -- & 11.2 & 467.7 & -- \\
\hline
\end{tabular}

1.Measured along the face of the most constricting side of the bridge.

2.Arbitrary datum for this study.

Table 2. Remaining footing/pile depth at abutments for the 500-year discharge at structure ROYATH00060030 on Town Highway 6, crossing the White River, Royalton, Vermont.

[VTAOT, Vermont Agency of Transportation; --, no data]

\begin{tabular}{|c|c|c|c|c|c|c|c|c|c|c|c|}
\hline Description & Station $^{1}$ & $\begin{array}{l}\text { VTAOT } \\
\text { minimum } \\
\text { bridge seat } \\
\text { elevation } \\
\text { (feet) }\end{array}$ & $\begin{array}{c}\text { Surveyed } \\
\text { minimum } \\
\text { low-chord } \\
\text { elevation } \\
\text { (feet) }\end{array}$ & $\begin{array}{c}\text { Bottom of } \\
\text { footing/pile } \\
\text { elevation } \\
\text { (feet) }\end{array}$ & $\begin{array}{c}\text { Channel } \\
\text { elevation at } \\
\text { abutment/ } \\
\text { pier }^{2} \\
\text { (feet) }\end{array}$ & $\begin{array}{l}\text { Contraction } \\
\text { scour depth } \\
\text { (feet) }\end{array}$ & $\begin{array}{c}\text { Abutment } \\
\text { scour } \\
\text { depth } \\
\text { (feet) }\end{array}$ & $\begin{array}{l}\text { Pier } \\
\text { scour } \\
\text { depth } \\
\text { (feet) }\end{array}$ & $\begin{array}{l}\text { Depth of } \\
\text { total scour } \\
\text { (feet) }\end{array}$ & $\begin{array}{c}\text { Elevation of } \\
\text { scour }^{2} \\
\text { (feet) }\end{array}$ & $\begin{array}{c}\text { Remaining } \\
\text { footing/pile } \\
\text { depth } \\
\text { (feet) }\end{array}$ \\
\hline \multicolumn{12}{|c|}{500 -year discharge is 79,320 cubic-feet per second } \\
\hline Left abutment & 0.0 & 97.9 & 503.2 & -- & 480.4 & 0.0 & 41.2 & -- & 41.2 & 439.2 & -- \\
\hline Right abutment & 158.9 & 98.2 & 503.4 & -- & 478.9 & 0.0 & 14.2 & -- & 14.2 & 464.7 & -- \\
\hline
\end{tabular}

1.Measured along the face of the most constricting side of the bridge.

2.Arbitrary datum for this study. 


\section{SELECTED REFERENCES}

Arcement, G.J., Jr., and Schneider, V.R., 1989, Guide for selecting Manning's roughness coefficients for natural channels and flood plains: U.S. Geological Survey Water-Supply Paper 2339, 38 p.

Barnes, H.H., Jr., 1967, Roughness characteristics of natural channels: U.S. Geological Survey Water-Supply Paper 1849,213 p.

Benson, M. A., 1962, Factors Influencing the Occurrence of Floods in a Humid Region of Diverse Terrain: U.S. Geological Survey WaterSupply Paper 1580-B, 64 p.

Brown, S.A. and Clyde, E.S., 1989, Design of riprap revetment: Federal Highway Administration Hydraulic Engineering Circular No. 11, Publication FHWA-IP-89-016, 156 p.

Federal Highway Administration, 1983, Runoff estimates for small watersheds and development of sound design: Federal Highway Administration Report FHWA-RD-77-158.

Federal Highway Administration, 1993, Stream Stability and Scour at Highway Bridges: Participant Workbook: Federal Highway Administration Report FHWA-HI-91-011.

Federal Emergency Management Agency, 1989, Flood Insurance Study, Town of Royalton, Windsor County, Vermont: Washington, D.C., June 5, 1989.

Froehlich, D.C., 1989, Local scour at bridge abutments in Ports, M.A., ed., Hydraulic Engineering--Proceedings of the 1989 National Conference on Hydraulic Engineering: New York, American Society of Civil Engineers, p. 13-18.

Hayes, D.C.,1993, Site selection and collection of bridge-scour data in Delaware, Maryland, and Virginia: U.S. Geological Survey WaterResources Investigation Report 93-4017, 23 p.

Interagency Advisory Committee on Water Data, 1982, Guidelines for determining flood flow frequency: U.S. Geological Survey, Bulletin 17B of the Hydrology Subcommittee, 190 p.

Johnson, C.G. and Tasker, G.D.,1974, Progress report on flood magnitude and frequency of Vermont streams: U.S. Geological Survey OpenFile Report 74-130, 37 p.

Lagasse, P.F., Schall, J.D., Johnson, F., Richardson, E.V., Chang, F., 1995, Stream Stability at Highway Structures: Federal Highway Administration Hydraulic Engineering Circular No. 20, Publication FHWA-IP-90-014, 144 p.

Laursen, E.M., 1960, Scour at bridge crossings: Journal of the Hydraulics Division, American Society of Civil Engineers, v. 86, no. HY2, p. 39-53.

Potter, W. D., 1957a, Peak rates of runoff in the Adirondack, White Mountains, and Maine woods area, Bureau of Public Roads

Potter, W. D., 1957b, Peak rates of runoff in the New England Hill and Lowland area, Bureau of Public Roads

Richardson, E.V. and Davis, S.R., 1995, Evaluating scour at bridges: Federal Highway Administration Hydraulic Engineering Circular No. 18, Publication FHWA-IP-90-017, 204 p.

Richardson, E.V., Simons, D.B., and Julien, P.Y., 1990, Highways in the river environment: Federal Highway Administration Publication FHWA-HI-90-016.

Ritter, D.F., 1984, Process Geomorphology: W.C. Brown Co., Debuque, Iowa, 603 p.

Shearman, J.O., 1990, User's manual for WSPRO--a computer model for water surface profile computations: Federal Highway Administration Publication FHWA-IP-89-027, 187 p.

Shearman, J.O., Kirby, W.H., Schneider, V.R., and Flippo, H.N., 1986, Bridge waterways analysis model; research report: Federal Highway Administration Publication FHWA-RD-86-108, 112 p.

Talbot, A.N., 1887, The determination of water-way for bridges and culverts.

U.S. Geological Survey, 1981, South Royalton, Vermont 7.5 Minute Series quadrangle map: U.S. Geological Survey Topographic Maps, Photoinspected 1983, Scale 1:24,000. 


\section{APPENDIX A: \\ WSPRO INPUT FILE}




\section{WSPRO INPUT FILE}

XS

GR

GR

GR

GR

GR

GR

GR

GR

$\mathrm{N}$

SA

*

$\mathrm{XS}$

*

*

BR

GR

GR

GR

GR

GR

GR

GR

GR

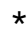

*

CD

$\mathrm{N}$

*

*

XR

GR

GR

GR

GR

GR

AS

GR

GR

GR

GR

GR

GR

GR

U.S. Geological Survey WSPRO Input File roya030.wsp Hydraulic analysis for structure ROYATH00060030 Date: 26-SEP-97 Bridge 30 on Sewall Brook Rd over White River Royalton, VT by MAI

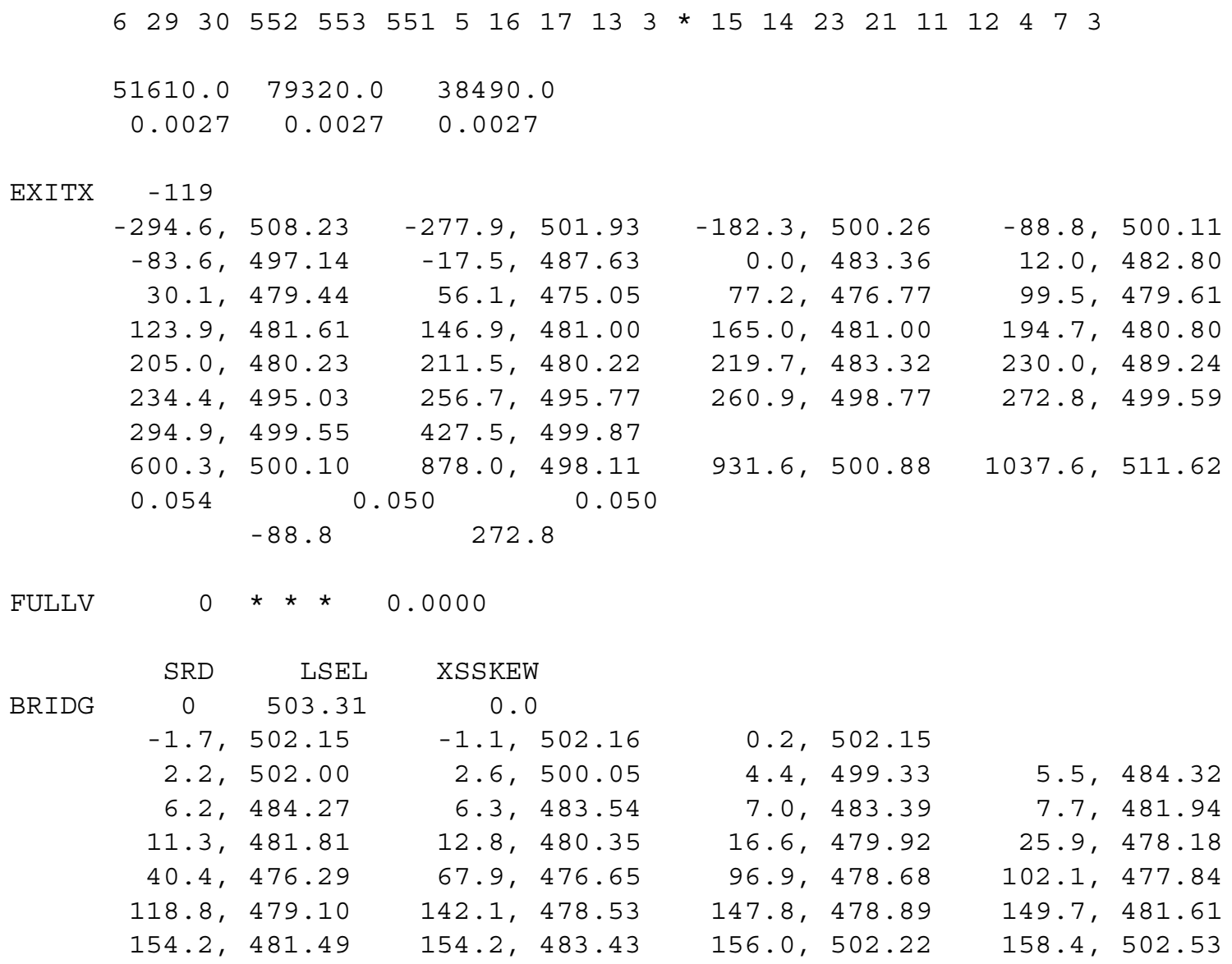

*

* The following points were omited to determine the incipient roadway-overtopping 
WSPRO INPUT FILE (continued)

* discharge. This prevents excessive flows on the overbank at a water surface

* below the top of the bank.

GR

GR

*

$\mathrm{N}$

SA

*

HP 1 BRIDG

HP 2 BRIDG

HP 2 RDWAY

HP 1 APPRO

HP 2 APPRO

*

HP 1 BRIDG

HP 2 BRIDG

HP 2 RDWAY

HP 1 APPRO

HP 2 APPRO

*

HP 1 BRIDG

HP 2 BRIDG

HP 1 APPRO

HP 2 APPRO

*

EX

$\mathrm{ER}$

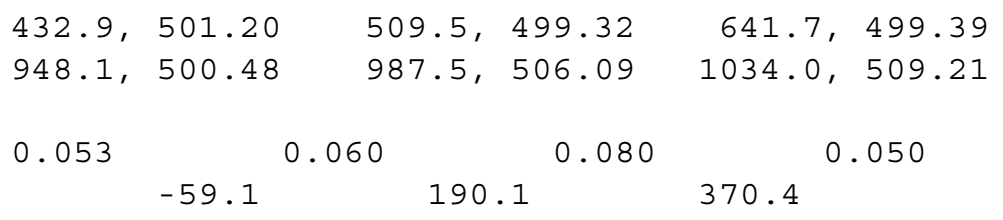

0.053

$-59.1$

0.060

190.1

0.080

370.4

499.961499 .96

$499.96 *$ * 37185

$502.45 *$ * 14425

502.921502 .92

502.92 * * 51610

503.421503 .42

$503.42 * * 39300$

$505.03 * * 39682$

505.931505 .93

505.93 * *79320

495.701495 .70

495.70 * * 38490

499.751499 .75

499.75 * * 38490 


\section{APPENDIX B: \\ WSPRO OUTPUT FILE}




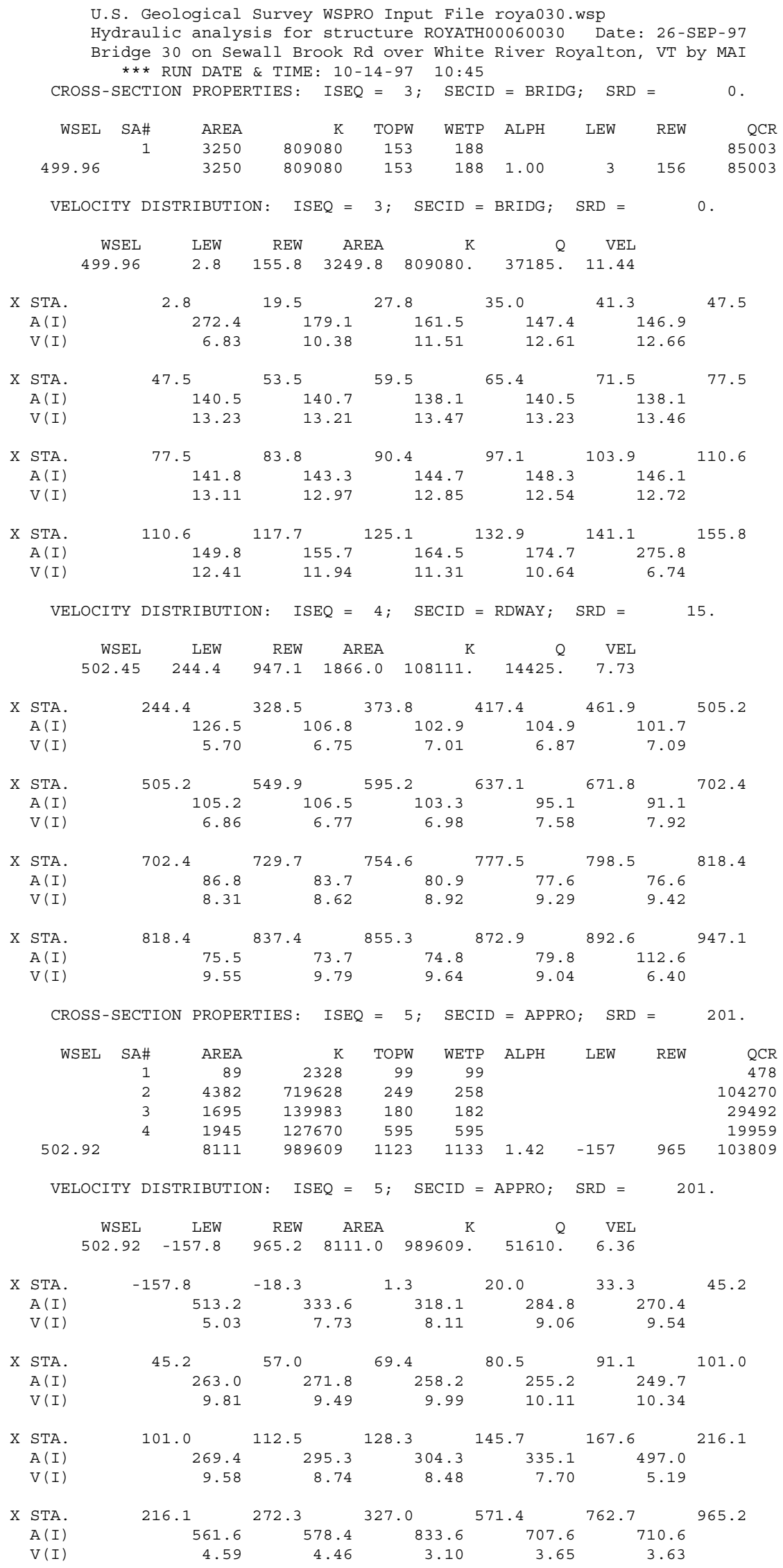


WSPRO OUTPUT FILE (continued)

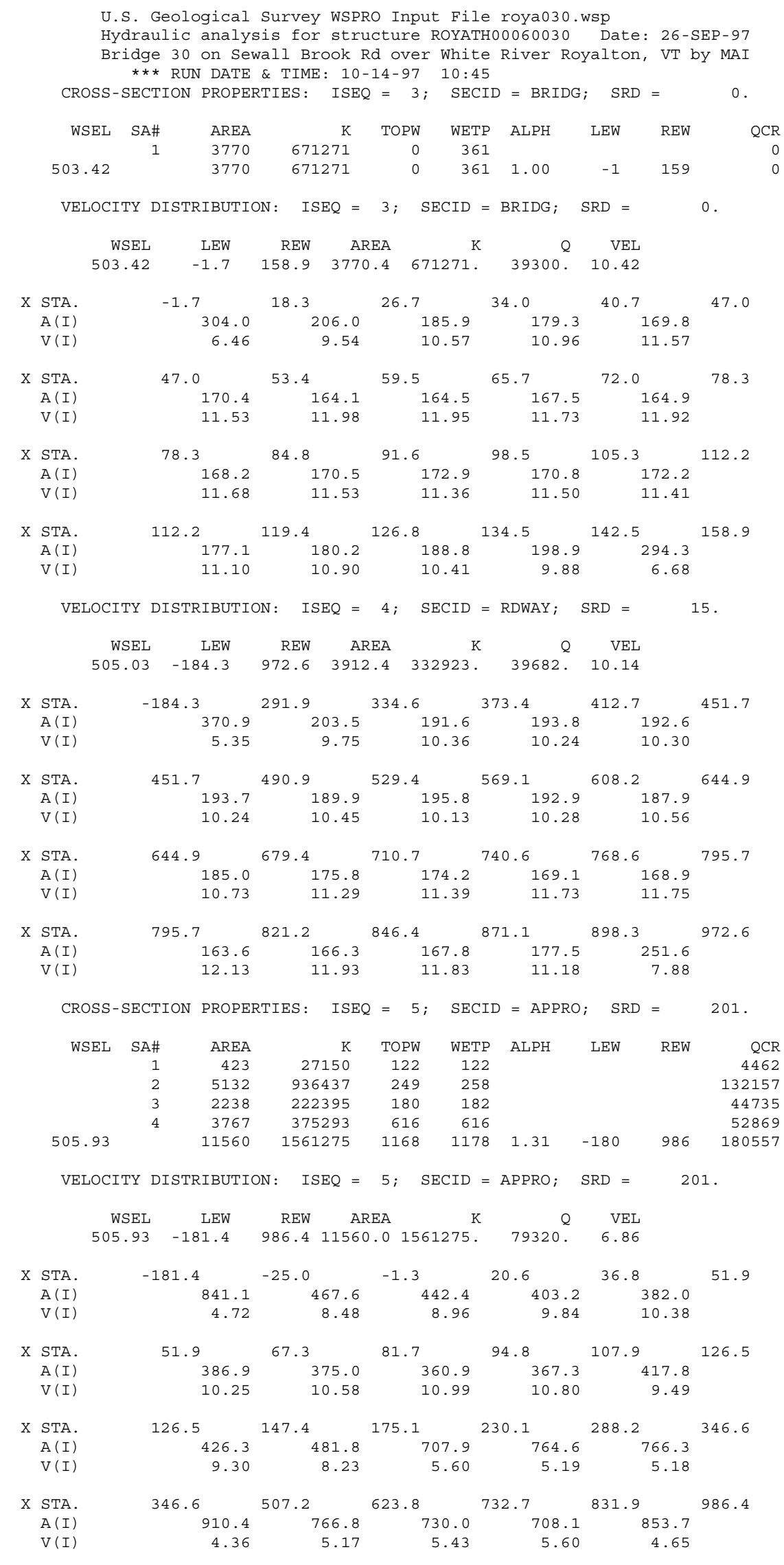


WSPRO OUTPUT FILE (continued)

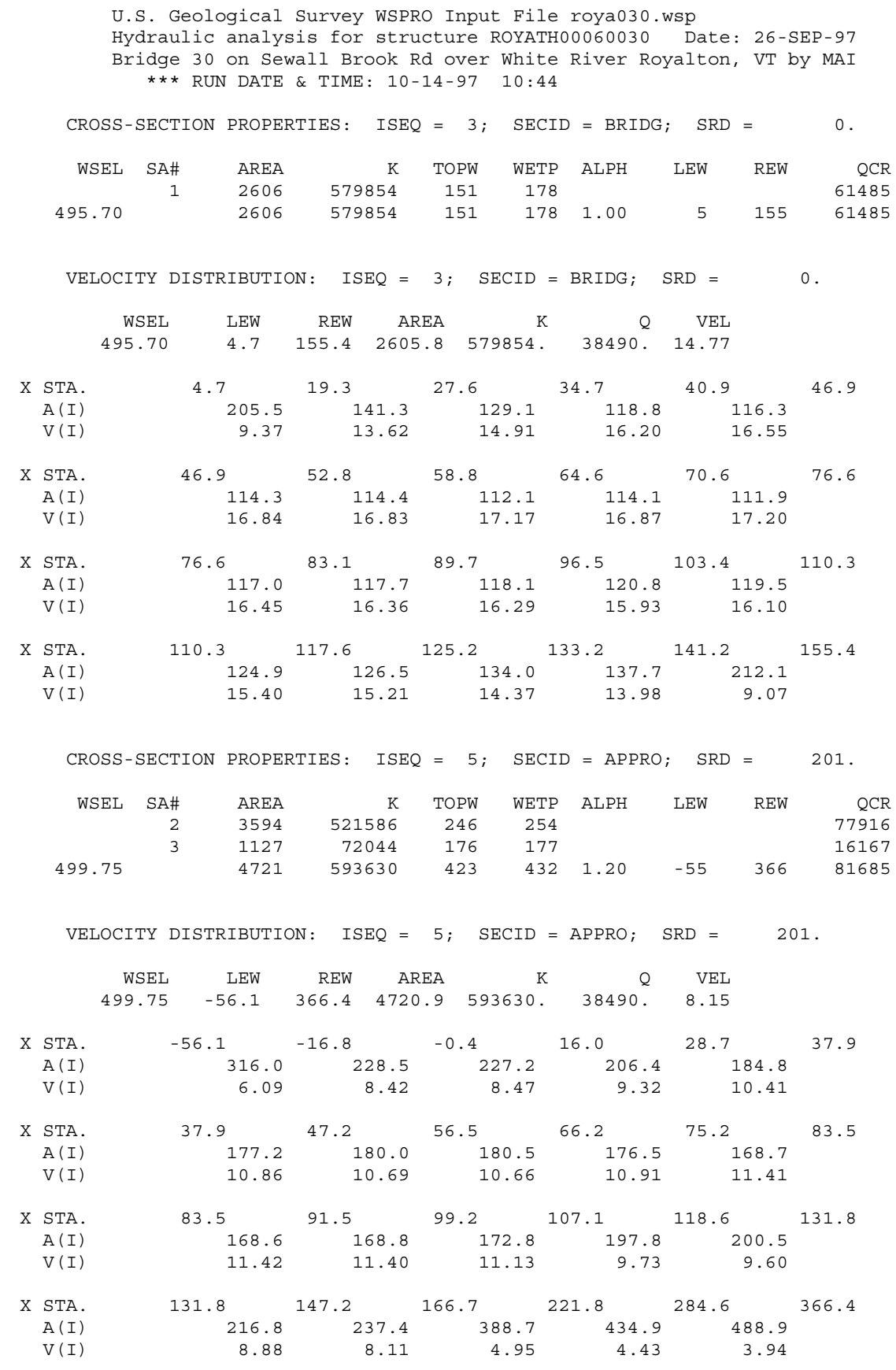


WSPRO OUTPUT FILE (continued)

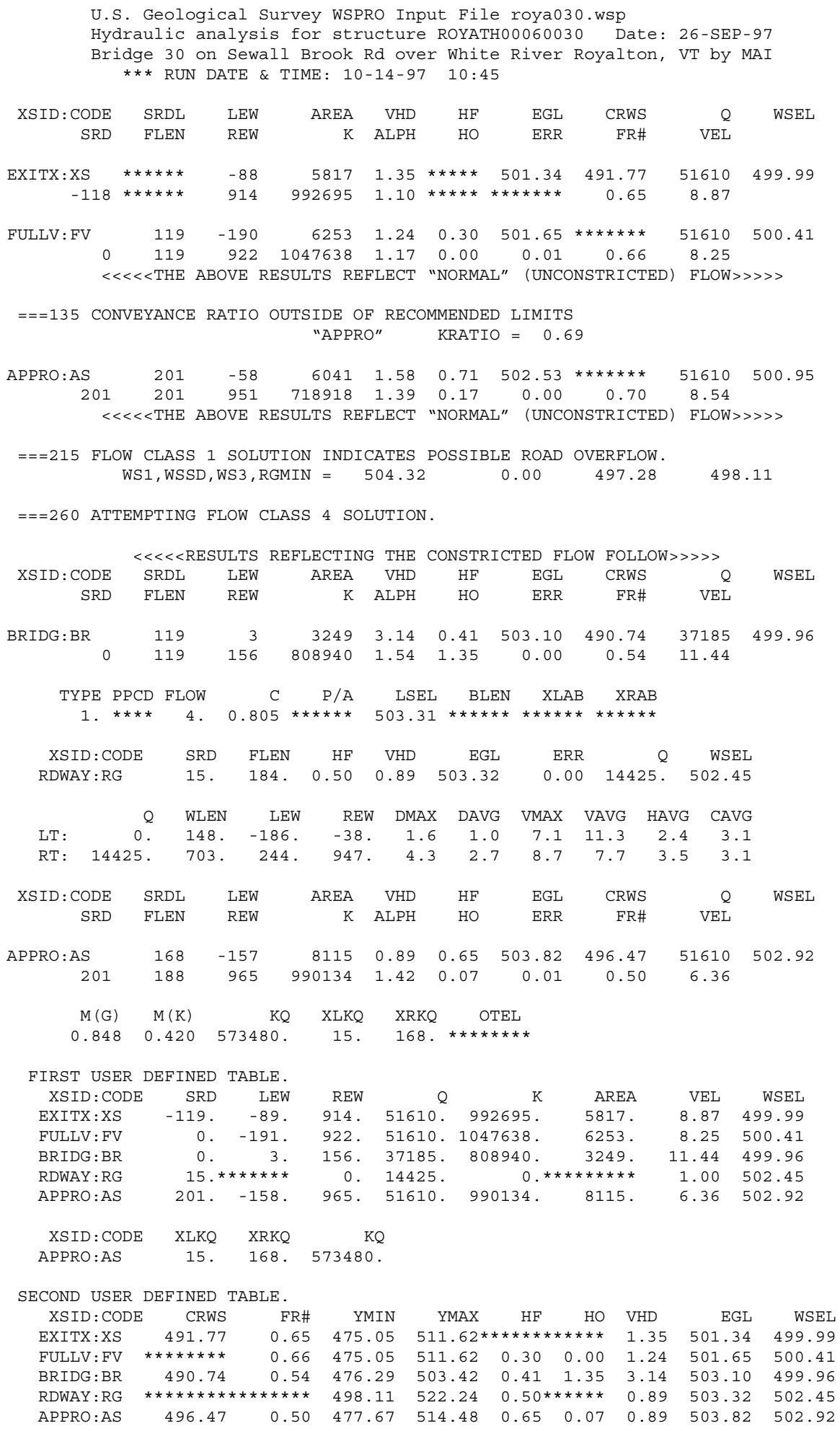


WSPRO OUTPUT FILE (continued)

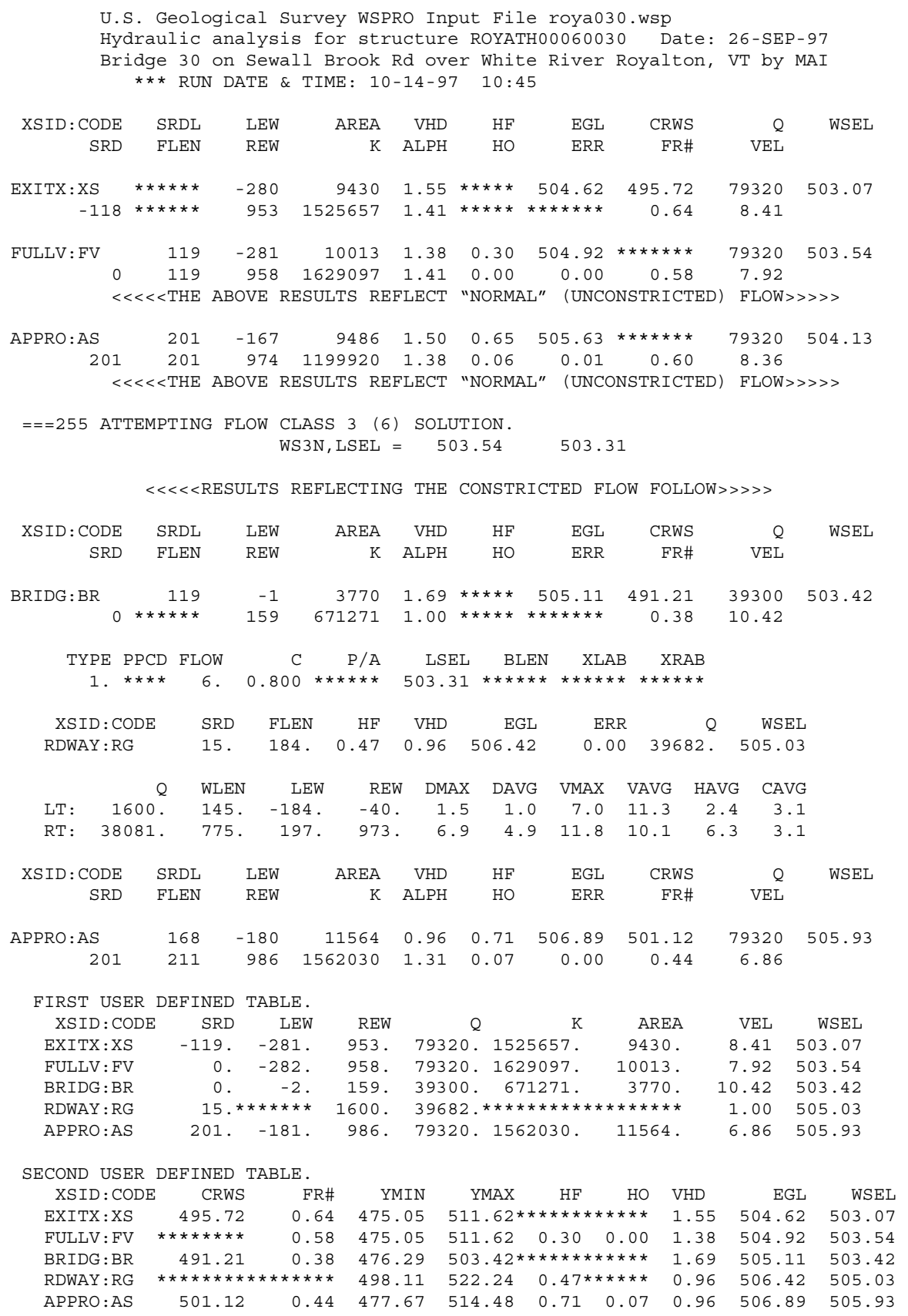


WSPRO OUTPUT FILE (continued)

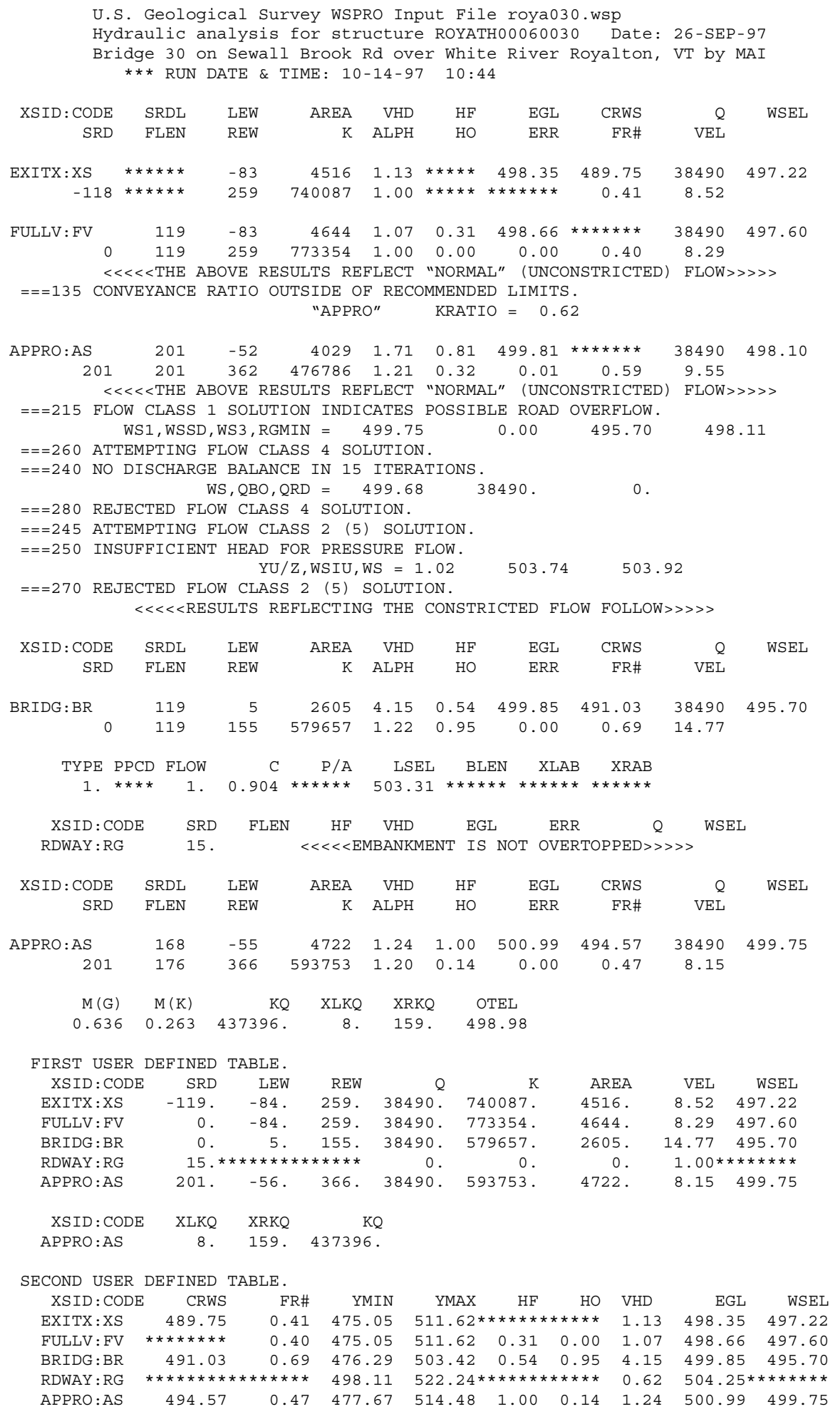




\section{APPENDIX C:}

\section{BED-MATERIAL PARTICLE-SIZE DISTRIBUTION}




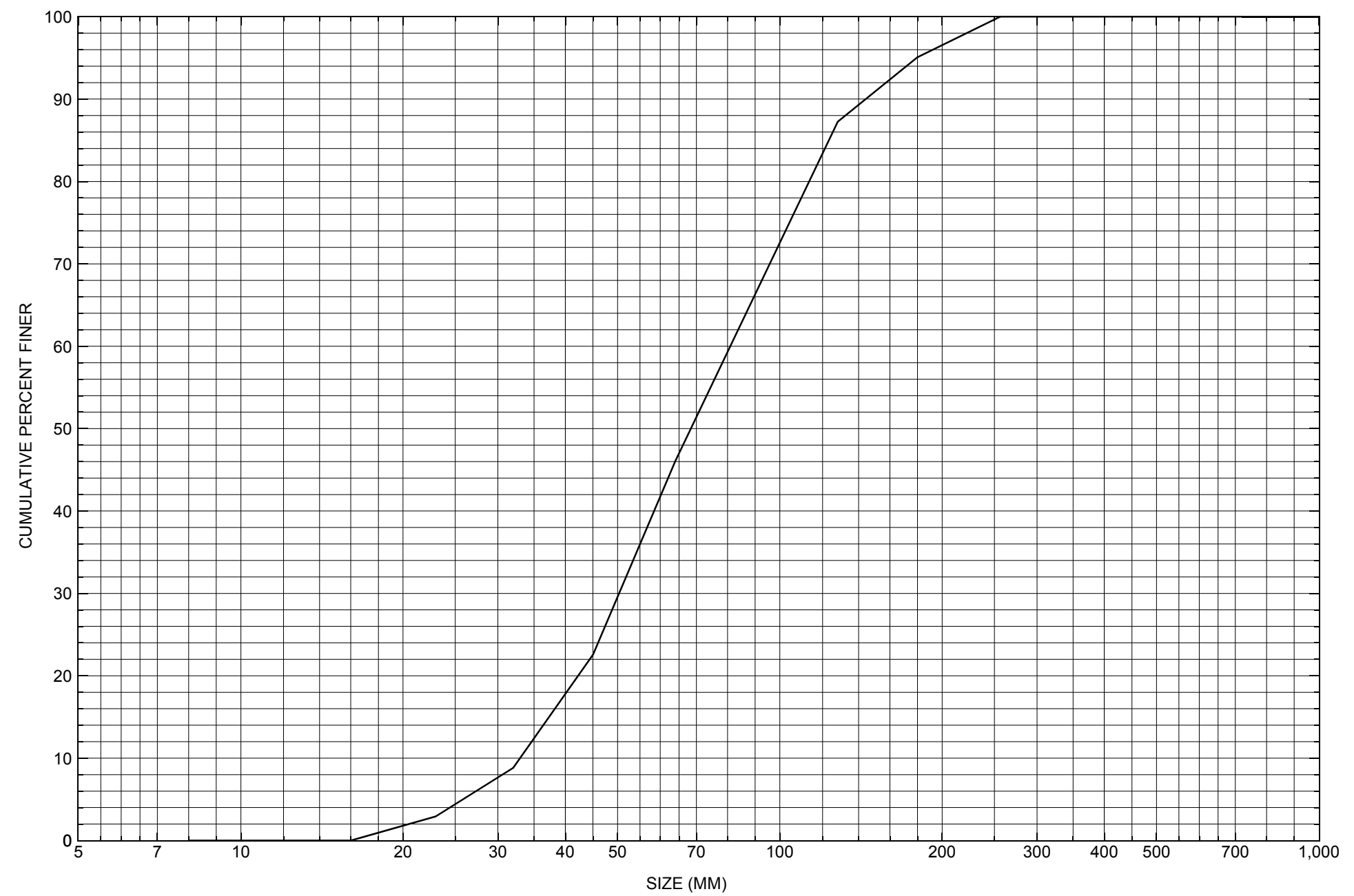

Appendix C. Bed material particle-size distribution for a pebble count in the channel approach of structure ROYATH00060030, in Royalton, Vermont. 


\section{APPENDIX D: \\ HISTORICAL DATA FORM}




\section{Structure Number ROYATH00060030}

\section{General Location Descriptive}

Data collected by (First Initial, Full last name) $\underline{\text { M. Ivanoff }}$

Date $(M M / D D / Y Y) \_\mathbf{0 5} / \underline{24} / \underline{95}$

Highway District Number (I - 2; nn) $\mathbf{0 4}$

Town (FIPS place code; I - 4; nnnnn) $\mathbf{6 0 8 5 0}$

Waterway (I - 6) White River

Route Number TH006

Topographic Map South Royalton

Latitude (I - 16; nnnn.n) $\mathbf{4 3 4 9 3}$
County (FIPS county code; I - 3; nnn)

Mile marker (I - 11; nnn.nnn) $\mathbf{0 0 0 0 0 0}$

Road Name (I - 7): Sewall Brook Road

Vicinity (I - 9) $\mathbf{0 . 1 5}$ miles to jet. with VT 14

Hydrologic Unit Code: $\mathbf{0 1 0 8 0 1 0 5}$

Longitude (i - 17; nnnnn.n) $\mathbf{7 2 3 4 9}$

\section{Select Federal Inventory Codes}

FHWA Structure Number (I - 8) 10141600301416

Maintenance responsibility $(I-21 ; n n) \_$03 $\quad$ Maximum span length $(I-48$; nnnn) $\underline{\mathbf{0 1 5 9}}$

Year built (I - 27; YYYY) 1928

Structure length (I - 49; nnnnnn) $\underline{\mathbf{0 0 0 1 6 5}}$

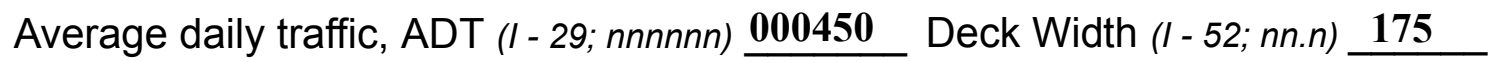

Year of ADT (I - 30; YY) $\mathbf{9 0}$

Channel \& Protection $(I-61 ; n) \underline{\mathbf{8}}$

Opening skew to Roadway $(I-34 ; n n) \quad \mathbf{0 0}$

Waterway adequacy $(I-71 ; n)$

Operational status $(I-41 ; X) \underline{P}$

Underwater Inspection Frequency $(I-92 B ; X Y Y) \_\mathbf{N}$

Structure type (I - 43; nnn) $\mathbf{3 1 0}$

Year Reconstructed (I - 106) $\mathbf{0 0 0 0}$

Approach span structure type $(I-44 ; n n n) \quad \mathbf{0 0 0}$

Clear span (nnn.n ft) _

Number of spans (I - 45; nnn) $\underline{\mathbf{0 0 1}}$

Vertical clearance from streambed (nnn.n ft) $\underline{\mathbf{2 5 . 0}}$

Number of approach spans (I - 46; nnnn) $\mathbf{0 0 0 0}$

Waterway of full opening $\left(n n n . n \mathrm{ft}^{2}\right)$

Comments:

The structural inspection report of $6 / 23 / 94$ indicates that the structure is a steel thru-truss bridge with an asphalt surface and approaches. The left abutment concrete was poured on ledge. The right abutment sits on silt. The timber pile tops were exposed from undermining (6-12 feet in from face) at the downstream end of the right abutment. Both footings had voids beneath them at one time which have been filled in with bags of concrete; in good condition. The waterway makes a moderate turn upstream. There is a ledge outcrop along the left abutment and stone and gravel bars along the right abutment. The channel scour along the left abutment has been remedied. Gravel bars were noted upstream and downstream. There is very little stone fill along the abutments. No embankment erosion was noted. 


\section{Bridge Hydrologic Data}

Is there hydrologic data available? $\underline{\mathbf{N}}$ if No, type ctrl-n $h \quad$ VTAOT Drainage area $\left(m i^{2}\right)$ : -

Terrain character:

Stream character \& type: -

Streambed material:

Discharge Data (cfs):

$$
\begin{aligned}
& \mathrm{Q}_{2.33}- \\
& \mathrm{Q}_{50}-
\end{aligned}
$$

$1-1=$

$$
\mathrm{Q}_{10} \ldots
$$$$
Q_{25} \ldots
$$

Water surface elevation (ft): -

Estimated Discharge (cfs): Velocity at $\mathrm{Q}$ (ft/s):

Ice conditions (Heavy, Moderate, Light) : Debris (Heavy, Moderate, Light):

The stage increases to maximum highwater elevation (Rapidly, Not rapidly):

The stream response is (Flashy, Not flashy):

Describe any significant site conditions upstream or downstream that may influence the stream's stage: The elevations of high water: extreme $101.2 \mathrm{ft}$ and normal $92.2 \mathrm{ft}$. The extreme low water elevation was at $80.6 \mathrm{ft}$.

The plans of 1928 indicated little drift and medium water velocity.

Watershed storage area (in percent):

The watershed storage area is: - _ (1-mainly at the headwaters; 2- uniformly distributed; 3-immediatly upstream oi the site)

Water Surface Elevation Estimates for Existing Structure:

\begin{tabular}{|l|l|l|l|l|l|}
\hline Peak discharge frequency & $Q_{2.33}$ & $Q_{10}$ & $Q_{25}$ & $Q_{50}$ & $Q_{100}$ \\
Water surface elevation (ft)) & - & - & - & - & - \\
Velocity (ft/sec) & - & - & - & - & - \\
\hline
\end{tabular}

Long term stream bed changes: -

Is the roadway overtopped below the $\mathrm{Q}_{100}$ ? (Yes, No, Unknown): $\mathbf{U}$ Frequency: Relief Elevation $(f t)$ : Discharge over roadway at $Q_{100}\left(f t^{3} / \mathrm{sec}\right)$ :

Are there other structures nearby? (Yes, No, Unknown): Y Upstream distance (miles): Town: If No or Unknown, type ctrl-n os Highway No. : I-89 Structure No. : Year Built:

Clear span (ft): Clear Height (ft): Full Waterway $\left(f t^{2}\right)$ : 
Downstream distance (miles): Town: Year Built:

Highway No. : Structure No. : Structure Type:

Clear span (ft): Clear Height $(f t)$ : Full Waterway $\left(f^{2}\right)$ : -

Comments:

\section{USGS Watershed Data}

Watershed Hydrographic Data

Drainage area (DA) $478.97 \mathrm{mi}^{2}$ Lake/pond/swamp area 0.92 $\mathrm{mi}^{2}$

Watershed storage (ST) 0.19

Bridge site elevation 480 $\%$

Main channel length $\mathbf{2 5 . 2 2}$ $\mathrm{ft}$

Headwater elevation 3780 $\mathrm{ft}$ $10 \%$ channel length elevation $\mathbf{5 1 0}$ $\mathrm{ft} \quad 85 \%$ channel length elevation 990 $\mathrm{ft}$

Main channel slope $(S)$ 18.17 $\mathrm{ft} / \mathrm{mi}$

Watershed Precipitation Data

Average site precipitation in Average headwater precipitation in

Maximum 2yr-24hr precipitation event $(124,2)$ in

Average seasonal snowfall (Sn) $\mathrm{ft}$ 


\section{Bridge Plan Data}

Are plans available? $\underline{\mathbf{Y}}$ If no, type ctrl-n pl Date issued for construction (MM/YYYY): $\underline{\mathbf{0 3}} / \mathbf{1 9 2 8}$ Project Number TH 6 B30 15-5-175

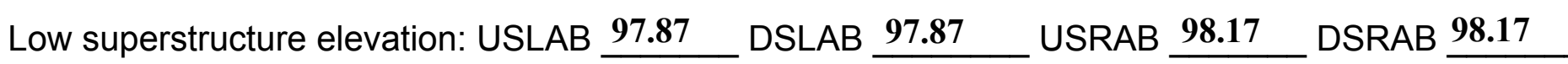
Benchmark location description:

BM\#1-Spike in root of a 14 inch poplar $218 \mathrm{ft}$ behind the left abutment on the upstream side and edge of the roadway, elevation $100.0 \mathrm{ft}$. BM\#2-Spike in trunk of a 12 inch elm on the upstream right bank $18 \mathrm{ft}$ behind the right abutment and 55 feet from the centerline of the roadway, elevation $97.26 \mathrm{ft}$.

Reference Point (MSL, Arbitrary, Other): Arbitrary Datum (NAD27, NAD83, Other): Arbitrary Foundation Type: $\mathbf{2}$ (1-Spreadfooting; 2-Pile; 3- Gravity; 4-Unknown)

If 1: Footing Thickness _ _ Footing bottom elevation: -

If 2: Pile Type: 1 (1-Wood; 2-Steel or metal; 3-Concrete) Approximate pile driven length:

If 3: Footing bottom elevation: -

Is boring information available? $\mathbf{N}$ If no, type ctrl-n bi Number of borings taken: _-

Foundation Material Type: $\mathbf{3}$ (1-regolith, 2-bedrock, 3-unknown)

Briefly describe material at foundation bottom elevation or around piles:

$-$

Comments:

The plans were for the replacement of the bridge seats in 1928 with about $2 \mathrm{ft}$ of the abutment tops excavated to set in the new concrete. The road approaches behind the abutments washed out in the flood prior to replacing the bridge deck. Piles may not have been used for the left abutment because the footing sits on bedrock. 


\section{Cross-sectional Data}

Is cross-sectional data available? Yes If no, type ctrl-n xs

Source (FEMA, VTAOT, Other)? FEMA

Comments: The station and elevation measurements are in feet.

\begin{tabular}{|l|l|l|l|l|l|l|l|l|l|l|l|}
\hline Station & 1008 & 1041 & 1082 & 1156 & - & - & - & - & - & - & - \\
\hline Feature & LAB & - & - & RAB & - & - & - & - & - & - & - \\
\hline $\begin{array}{l}\text { Low chord } \\
\text { elevation }\end{array}$ & 501 & $\mathbf{5 0 1 . 5}$ & $\mathbf{5 0 2}$ & $\mathbf{5 0 1}$ & - & - & - & - & - & - & - \\
\hline $\begin{array}{l}\text { Bed } \\
\text { elevation }\end{array}$ & 482 & 478 & 478 & 478 & - & - & - & - & - & - & - \\
\hline $\begin{array}{l}\text { Low chord- } \\
\text { bed }\end{array}$ & 19 & 23.5 & 24 & 23 & - & - & - & - & - & - & - \\
\hline Station & - & - & - & - & - & - & - & - & - & - & - \\
\hline Feature & - & - & - & - & - & - & - & - & - & - & - \\
\hline $\begin{array}{l}\text { Low chord } \\
\text { elevation }\end{array}$ & - & - & - & - & - & - & - & - & - & - & - \\
\hline $\begin{array}{l}\text { Bed } \\
\text { elevation }\end{array}$ & - & - & - & - & - & - & - & - & - & - & - \\
\hline $\begin{array}{l}\text { Low chord- } \\
\text { bed }\end{array}$ & - & - & - & - & - & - & - & - & - & - & - \\
\hline
\end{tabular}

Source (FEMA, VTAOT, Other)?

Comments: -

\begin{tabular}{|l|l|l|l|l|l|l|l|l|l|l|l|}
\hline Station & - & - & - & - & - & - & - & - & - & - & - \\
\hline Feature & - & - & - & & - & - & - & - & - & - & - \\
\hline $\begin{array}{l}\text { Low chord } \\
\text { elevation }\end{array}$ & - & - & - & & - & - & - & - & - & - & - \\
\hline $\begin{array}{l}\text { Bed } \\
\text { elevation }\end{array}$ & - & - & - & - & - & - & - & - & - & - & - \\
\hline $\begin{array}{l}\text { Low chord- } \\
\text { bed }\end{array}$ & - & - & - & - & - & - & - & - & - & - & - \\
\hline Station & - & - & - & - & - & - & - & - & - & - & - \\
\hline Feature & - & - & - & - & - & - & - & - & - & - & - \\
\hline $\begin{array}{l}\text { Low chord } \\
\text { elevation }\end{array}$ & - & - & - & - & - & - & - & - & - & - & - \\
\hline $\begin{array}{l}\text { Bed } \\
\text { elevation }\end{array}$ & - & - & - & - & - & - & - & - & - & - & - \\
\hline $\begin{array}{l}\text { Low chord- } \\
\text { bed }\end{array}$ & - & - & - & - & - & - & - & - & - & - & - \\
\hline
\end{tabular}




\section{APPENDIX E: \\ LEVEL I DATA FORM}


U. S. Geological Survey

Bridge Field Data Collection and Processing Form

Qa/Qc Check by: $\underline{\text { EW Date: } 11 / 5 / 96}$

\section{Structure Number}

ROYATH00060030

\section{A. General Location Descriptive}

1. Data collected by (First Initial, Full last name) $\underline{\mathbf{R}}$. Hammond

2. Highway District Number 04

County Windsor (027)

Waterway (I - 6) White River

Route Number TH 6

3. Descriptive comments:

The site is located 0.15 miles from the junction with State Route 14.
Mile marker $\mathbf{0 0 0 0 0 0}$

Town Royalton (60850)

Road Name Sewall Brook Road

Hydrologic Unit Code: $\mathbf{0 1 0 8 0 1 0 5}$

Date $(M M / D D / Y Y) \underline{\mathbf{0 7} / \mathbf{0 8} / 1996}$

\section{B. Bridge Deck Observations}
4. Surface cover... LBUS 5
RBUS 4
LBDS 5
RBDS 4
Overall 4

(2b us,ds,lb,rb: 1- Urban; 2- Suburban; 3- Row crops; 4- Pasture; 5- Shru $b$ - and brushland; 6- Forest; 7- Wetland)
5. Ambient water surface... US $\underline{2}$
UB 1
DS 1
(1- pool; 2- riffle)

6. Bridge structure type 1 (1- single span; 2- multiple span; 3- single arch; 4- multiple arch; 5-cylindrical culvert; 6- box culvert; or 7-other)
7. Bridge length 165 (feet)
Span length 159 (feet)
Bridge width $\underline{\mathbf{1 7 . 5}}$ (feet)

\section{Road approach to bridge:}
8. LB 1 RB 1
( 0 even, 1- lower, 2- higher)
9. LB_ 1 RB 1
(1-Paved, 2- Not paved)

10. Embankment slope (run / rise in feet / foot):

US left

US right

\begin{tabular}{|c|c|c|c|}
\hline \multicolumn{2}{|c|}{ Protection } & \multirow{2}{*}{ 13.Erosion } & \multirow{2}{*}{ 14.Severity } \\
\hline 11.Type & 12.Cond. & & \\
\hline 5 & & 0 & \\
\hline
\end{tabular}

LBUS

RBUS

RBDS

LBDS

\begin{tabular}{l|l}
$\frac{5}{2}$ & $\frac{1}{1}$ \\
\hline 2 & 2 \\
\hline 5 & 1 \\
\hline
\end{tabular}

\begin{tabular}{l}
$\mathbf{0}$ \\
\hline $\mathbf{0}$ \\
\hline $\mathbf{0}$ \\
\hline
\end{tabular}

Bank protection types: 0- none; 1- < 12 inches,

2- $<36$ inches; $3-<48$ inches;

4- < 60 inches; 5- wall / artificial levee

Bank protection conditions: 1- good; 2- slumped;

3- eroded; 4- failed

Erosion: 0 - none; 1- channel erosion; 2-

road wash; 3- both; 4- other

Erosion Severity: 0 - none; 1- slight; 2- moderate; 3- severe

\section{Channel approach to bridge (BF):}

15. Angle of approach: $\mathbf{0}$

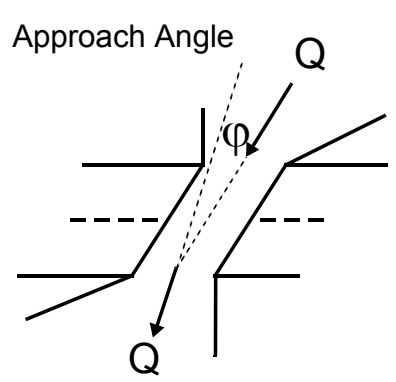

17. Channel impact zone 1 :

Where? LB $(L B, R B)$

Range? $\underline{300}$ feet $\underline{\text { US }}$

Channel impact zone 2:

Where? RB (LB, RB)

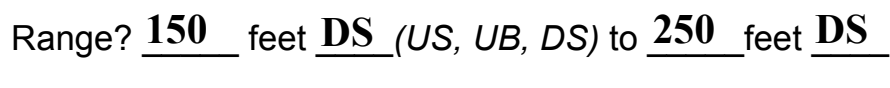

Impact Severity: 0- none to very slight; 1- Slight; 2-Moderate; 3- Severe
16. Bridge skew: 10

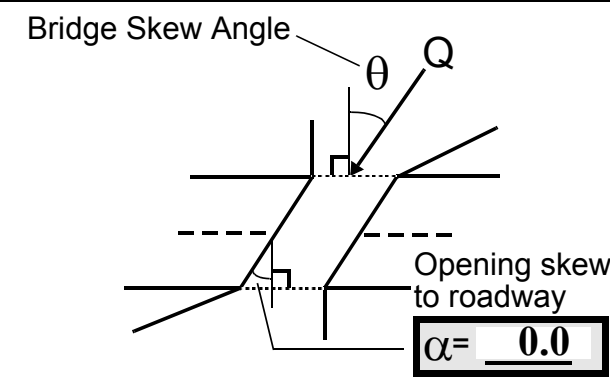

\section{Exist? $\mathbf{Y}(Y$ or $N)$}

Severity 2

(US, UB, DS) to 170 feet $\underline{\mathbf{U S}}$

Exist? $\underline{\mathbf{Y}}(\mathrm{Y}$ or $N)$

Severity 2 
18. Bridge Type: $1 \mathbf{1 b} / \mathbf{1 a}$

1a- Vertical abutments with wingwalls

1 b- Vertical abutments without wingwalls

2- Vertical abutments and wingwalls, sloping embankment Wingwalls parallel to abut. face

3- Spill through abutments

4- Sloping embankment, vertical wingwalls and abutments Wingwall angle less than $90^{\circ}$.

19. Bridge Deck Comments (surface cover variations, measured bridge and span lengths, bridge type variations, approach overflow width, etc.)

4: The right bank surface cover is trees to the road, then it is an alfalfa field. The left bank surface cover is a combination of scattered trees, shrubs and lawn.

7: The bridge dimension values are from VTAOT. The measured values during the site visit are: bridge length $=162 \mathrm{ft}$; bridge span $=154 \mathrm{ft}$; and bridge width $=17.4 \mathrm{ft}$.

18: The bridge type is $1 \mathrm{~b}$ on the left side of the channel, and $1 \mathrm{a}$ on the right side of the channel.

\section{Upstream Channel Assessment}

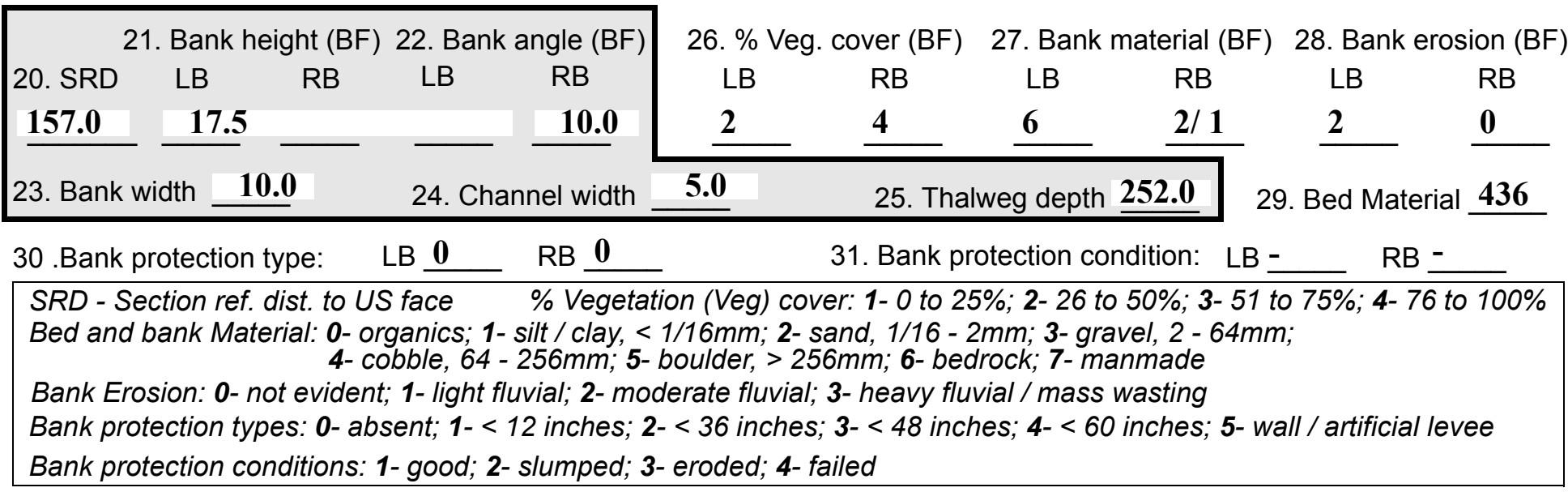

32. Comments (bank material variation, minor inflows, protection extent, etc.):

27: There is ledge outcrops all along the upstream left bank. 
36. Point bar extent: $\underline{\mathbf{5 0 0}}$ feet $\underline{\text { US }}$ (US, UB) to $\underline{\mathbf{1 5 0}}$ feet $\underline{\mathrm{US}}$ (US, UB, DS) positioned $\underline{\mathbf{7 0}} \%$ LB to $\underline{\mathbf{1 0 0}} \%$ RB

37. Material: 43

38. Point or side bar comments (Circle Point)or Side; Note additional bars, material variation, status, etc.):

39. Is a cut-bank present? $\mathbf{Y}$ (Y or if $N$ type ctrl-n cb)

40. Where? LB (LB or RB)

41. Mid-bank distance: $\mathbf{1 2 0}$

42. Cut bank extent: 140 feet $\underline{\mathbf{U S}}$

(US, UB) to $\underline{\mathbf{1 0 0}}$ feet $\underline{\mathbf{U S}}$ (US, UB, DS)

43. Bank damage: 1

(1- eroded and/or creep; 2- slip failure; 3- block failure)

44. Cut bank comments (eg. additional cut banks, protection condition, etc.):

The cut-bank is downstream of a rock outcrop, upstream of the left abutment and road embankment on ledge which forms a large eddy and cuts into the left bank ledge.

\section{Is channel scour present? $\mathbf{Y}$ ( $Y$ or if $N$ type ctrl-n cs) $\quad$ 46. Mid-scour distance: 100}
47. Scour dimensions: Length $\mathbf{8 0}$
Width 140
Depth : 12
Position $\underline{\mathbf{1 0}} \%$ LB to $\underline{\mathbf{8 0}} \%$ RB

48. Scour comments (eg. additional scour areas, local scouring process, etc.):

The scour hole exists between two ledge outcrops, refer to the plan view sketch.

\section{Are there major confluences? $\mathbf{Y}$ ( $Y$ or if $N$ type ctrl-n $m c)$ \\ 51. Confluence 1: Distance $\mathbf{9 0 0}$ US \\ Confluence 2: Distance - \\ 52. Enters on $\underline{\mathbf{L B}}$ (LB or RB) \\ Enters on - (LB or $R B)$}

54. Confluence comments (eg. confluence name):

50. How many? 1

53. Type 1 (1-perennial; 2-ephemeral)

Type (1- perennial; 2-ephemeral)

The tributary is the Third Branch of the White River.

\section{Under Bridge Channel Assessment}

55. Channel restraint (BF)? LB 2

\begin{tabular}{|ccccc}
\hline \multicolumn{2}{|c}{56. Height (BF) } & \multicolumn{3}{c}{57 Angle (BF) } \\
LB & RB & LB & RB \\
$\mathbf{9 7 . 5}$ & & & $\mathbf{5 . 5}$ & \\
\hline
\end{tabular}

58. Bank width (BF) -

59. Channel width -
61. Material (BF)

LB RB

$2 \quad 7$
62. Erosion (BF)

LB RB

7

Bed and bank Material: 0- organics; 1- silt / clay, < 1/16mm; 2- sand, 1/16 - 2mm; 3- gravel, 2 - 64mm; 4- cobble, 64 - 256mm; 5- boulder, > 256mm; 6- bedrock; 7- manmade

Bank Erosion: 0- not evident; 1- light fluvial; 2- moderate fluvial; 3- heavy fluvial / mass wasting

64. Comments (bank material variation, minor inflows, protection extent, etc.):

43

62: The right abutment shows some signs of deterioration comprised of spalled/ broken concrete off the top of footing, at the downstream end, exposing the tops of logs. Bags of concrete have been placed along the abutment footing for protection. The bag dimensions are $4 \mathrm{ft} \times 4 \mathrm{ft} \times 1.5 \mathrm{ft}$.

The left abutment also shows some signs of deterioration of the concrete footing. 
65. Debris and Ice Is there debris accumulation?

(Yor $N)$ 66. Where? $\underline{Y}$

(1- Upstream; 2- At bridge; 3- Both)

67. Debris Potential $\underline{3}$

( 1- Low; 2- Moderate; 3- High)

68. Capture Efficiency 1

(1-Low; 2- Moderate; 3- High)

69. Is there evidence of ice build-up? 1 ( $Y$ or $N)$

Ice Blockage Potential $\underline{Y}$

(1-Low; 2- Moderate; 3- High)

70. Debris and Ice Comments:

2

There are trees leaning over the upstream channel. There is evidence of ice build-up along the faces and the upstream corners of the abutments.

\begin{tabular}{|l|c|c|c|c|c|c|c|c|}
\hline Abutments & $\begin{array}{c}\text { 71. Attack } \\
\angle \text { (BF) }\end{array}$ & $\begin{array}{c}\text { 72. Slope } \angle \\
\text { (Qmax) }\end{array}$ & $\begin{array}{l}\text { 73. Toe } \\
\text { loc. (BF) }\end{array}$ & $\begin{array}{c}\text { 74. Scour } \\
\text { Condition }\end{array}$ & $\begin{array}{c}\text { 75. Scour } \\
\text { depth }\end{array}$ & $\begin{array}{c}\text { 76. Exposure } \\
\text { depth }\end{array}$ & 77. Material & 78. Length \\
\hline LABUT & & $\mathbf{0}$ & $\mathbf{9 0}$ & $\mathbf{2}$ & $\mathbf{2}$ & $\mathbf{0}$ & $\mathbf{2}$ & $\mathbf{9 0 . 0}$ \\
\hline RABUT & $\mathbf{1}$ & $\mathbf{1 0}$ & $\mathbf{9 0}$ & & & $\mathbf{2}$ & $\mathbf{2}$ & $\mathbf{1 5 9 . 0}$ \\
\hline
\end{tabular}

Pushed: $L B$ or RB

Toe Location (Loc.): 0- even, 1- set back, 2- protrudes

Scour cond.: 0- not evident; 1- evident (comment); 2- footing exposed; 3-undermined footing; 4- piling exposed; 5- settled; 6- failed

Materials: 1- Concrete; 2- Stone masonry or drywall; 3- steel or metal; 4- wood

79. Abutment comments (eg. undermined penetration, unusual scour processes, debris, etc.):

0

1

1

74/ 75: There is a bedrock ledge visible at the base of the concrete bags in front of the left abutment footing.

74/ 75: The concrete bags protect the abutment footings. There is no observable scour near the bags.

80. Wingwalls:

$\begin{array}{lllll} & & & & \\ \text { Exist? } & & & \\ & & & & \\ \text { Condition? } & \text { depth? } & \text { depth? }\end{array}$

USLWW:

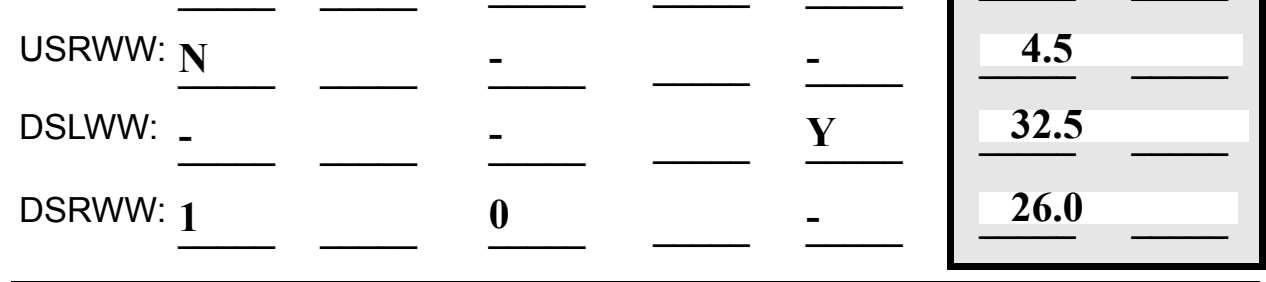

Wingwall materials: 1- Concrete; 2- Stone masonry or drywall; 3- steel or metal; 4- wood

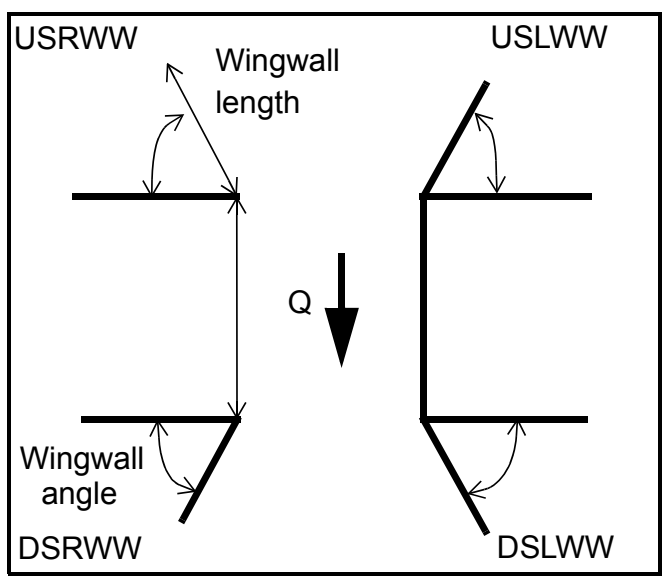

82. Bank / Bridge Protection:

\begin{tabular}{|l|l|l|l|l|l|l|l|c|}
\hline Location & USLWW & USRWW & LABUT & RABUT & LB & RB & DSLWW & DSRWW \\
\hline Type & - & - & $\mathbf{Y}$ & - & - & $\mathbf{1}$ & $\mathbf{1}$ & $\mathbf{1}$ \\
\hline Condition & $\mathbf{N}$ & - & $\mathbf{1}$ & - & - & $\mathbf{1}$ & $\mathbf{1}$ & $\mathbf{1}$ \\
\hline Extent & - & - & $\mathbf{0}$ & - & $\mathbf{2}$ & $\mathbf{5}$ & $\mathbf{5}$ & - \\
\hline
\end{tabular}

Bank / Bridge protection types: 0- absent; 1- < 12 inches; 2- < 36 inches; 3- < 48 inches; 4- < 60 inches; 
83. Wingwall and protection comments (eg. undermined penetration, unusual scour processes, etc.):

-
-
-
-
-
-
-
-
3
1
1

\section{Piers:}

84. Are there piers? Th (Y or if $N$ type ctrl-n pr)

\begin{tabular}{|l|c|l|l|l|l|l|l|}
\hline \multirow{2}{*}{$\begin{array}{l}85 . \\
\text { Pier no. }\end{array}$} & \multicolumn{3}{|c|}{ width (w) feet } & \multicolumn{3}{c|}{ elevation (e) feet } \\
\cline { 2 - 8 } & w1 & w2 & w3 & e@w1 & e@w2 & e@w3 \\
\hline Pier 1 & -- & & & - & $\mathbf{2 0 . 0}$ & $\mathbf{1 9 . 0}$ \\
\hline Pier 2 & -- & & & -- & $\mathbf{4 0 . 0}$ & $\mathbf{2 2 . 0}$ \\
\hline Pier 3 & - & - & - & - & - & - \\
\hline Pier 4 & - & - & - & - & - & - \\
\hline
\end{tabular}

\begin{tabular}{|l|l|l|l|l|}
\hline Level 1 Pier Descr. & \multicolumn{1}{|c|}{1} & \multicolumn{1}{|c|}{2} & \multicolumn{1}{|c|}{3} & \multicolumn{1}{|c|}{ 86. Location (BF) } \\
\hline 87. Type & e left & crete & of the & N \\
\hline 88. Material & and & bags & foot- & - \\
\hline 89. Shape & right & that & ings. & - \\
\hline 90. Inclined? & abut & are & & - \\
\hline 91. Attack $\angle$ (BF) & pro- & ed & & - \\
\hline 92. Pushed & tec- & ver- & & - \\
\hline 93. Length (feet) & - & - & - & - \\
\hline 94. \# of piles & tion & ticall & & - \\
\hline 95. Cross-members & con- & y & & - \\
\hline 96. Scour Condition & sist & alon & & - \\
\hline 97. Scour depth & of & g the & & - \\
\hline 98. Exposure depth & con- & base & & - \\
\hline
\end{tabular}

LFP, LTB, LB, MCL, MCM, MCR, RB, RTB, RFP

1- Solid pier, 2- column, 3- bent

1-Wood; 2- concrete; 3- metal; 4- stone

1- Round; 2- Square; 3- Pointed

Y-yes; $N$ - no

$L B$ or $R B$

0- none; 1- laterals; 2- diagonals; 3- both

0- not evident; 1- evident (comment);

2- footing exposed; 3- piling exposed;

4- undermined footing; 5- settled; 6- failed 
99. Pier comments (eg. undermined penetration, protection and protection extent, unusual scour processes, etc.):

-
-
-
-
-
-
-
-
-
-

100.

\section{E. Downstream Channel Assessment}

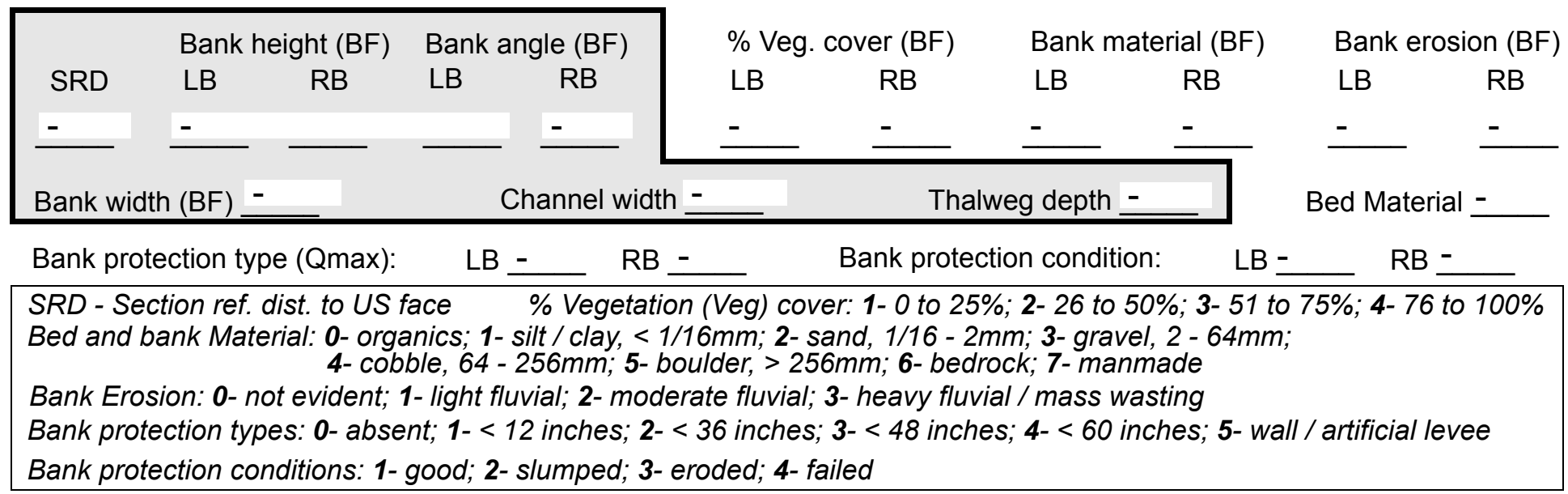

Comments (eg. bank material variation, minor inflows, protection extent, etc.):

-
-
-
-
-
-
-
-
-
-
-
-
-
-
-

101. Is a drop structure present? _ ( $Y$ or $N$, if $N$ type ctrl-n ds) 102. Distance: ___ feet

103. Drop: -_ feet 104. Structure material: NO (1- steel sheet pile; 2- wood pile; 3- concrete; 4- other) 105. Drop structure comments (eg. downstream scour depth):

PIERS 
Point bar extent: feet 3

(US, UB, DS) to $\mathbf{3}$ feet 216 (US, UB

UB, DS) positioned 2 $213 \%$ \%B to 1 $\%$ RB

Material: 1

Point or side bar comments (Circle Point or side) note additional bars, material variation, status, etc.):

\section{2}

0

0

$-$

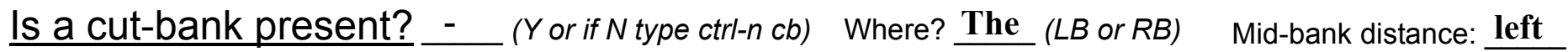
Cut bank extent: bank feet ero (US, UB, DS) to sion feet is a (US, UB, DS)

Bank damage: res (1- eroded and/or creep; 2- slip failure; 3- block failure)

Cut bank comments (eg. additional cut banks, protection condition, etc.):

ult of eddy currents.

Is channel scour present? ( $Y$ or if $N$ type ctrl-n $c s)$

Mid-scour distance:

Scour dimensions: Length Width Depth:

Positioned $\%$ LB to $\% \mathrm{RB}$

Scour comments (eg. additional scour areas, local scouring process, etc.):

Are there major confluences? $\mathbf{N}$ ( $Y$ or if $N$ type ctrl-n $m c)$

Confluence 1: Distance NO

Confluence 2: Distance $\underline{\text { STR }}$

Confluence comments (eg. confluence name):

RE
Enters on $\underline{\mathbf{D R}}$ ( $L B$ or $R B)$

Enters on $\underline{\mathbf{U C}}$ (LB or RB)
How many? -

Type $\underline{\text { OP }}$ (1- perennial; 2- ephemeral)

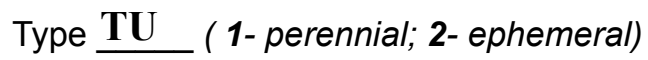

\section{F. Geomorphic Channel Assessment}

107. Stage of reach evolution
1- Constructed

2- Stable

3- Aggraded

4- Degraded

5- Laterally unstable

6- Vertically and laterally unstable 
108. Evolution comments (Channel evolution not considering bridge effects; See HEC-20, Figure 1 for geomorphic descriptors):

Y
$\mathbf{3 5 0}$
$\mathbf{8 0}$
160
DS
$>\mathbf{5 0 0}$
DS
0
60
43




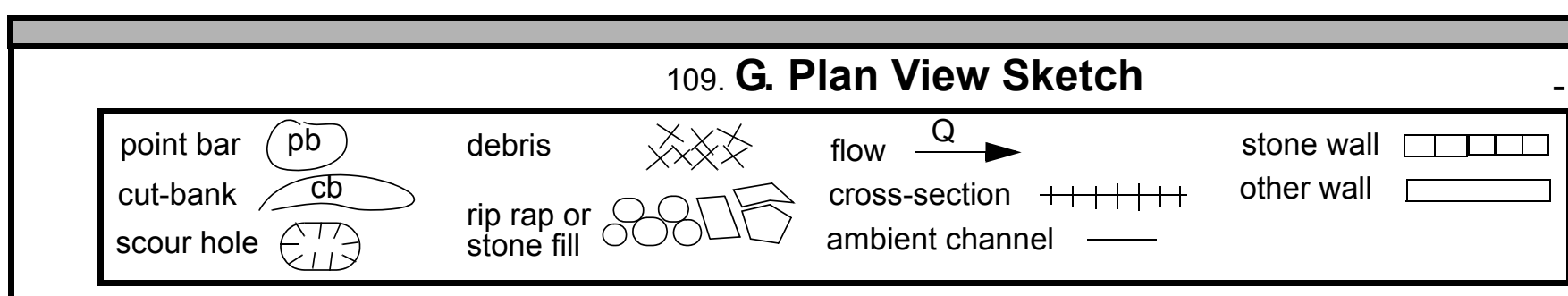

cut-bank $\mathrm{cb}$

scour hole rip rap or
stone fill stone fill cross-section $+1+1+1$ ambient channe other wall 
APPENDIX F:

SCOUR COMPUTATIONS 


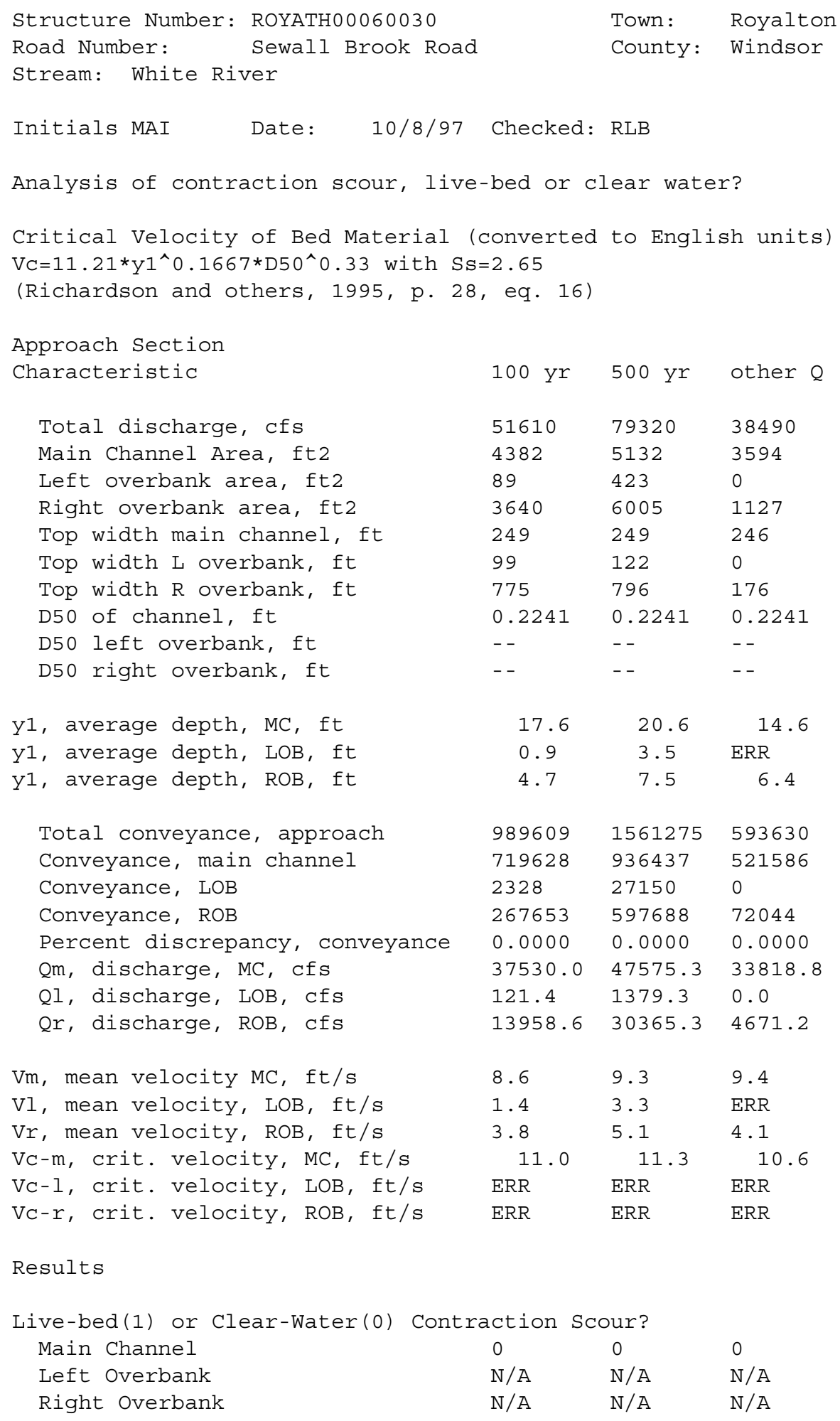


Clear water Contraction Scour in MAIN CHANNEL

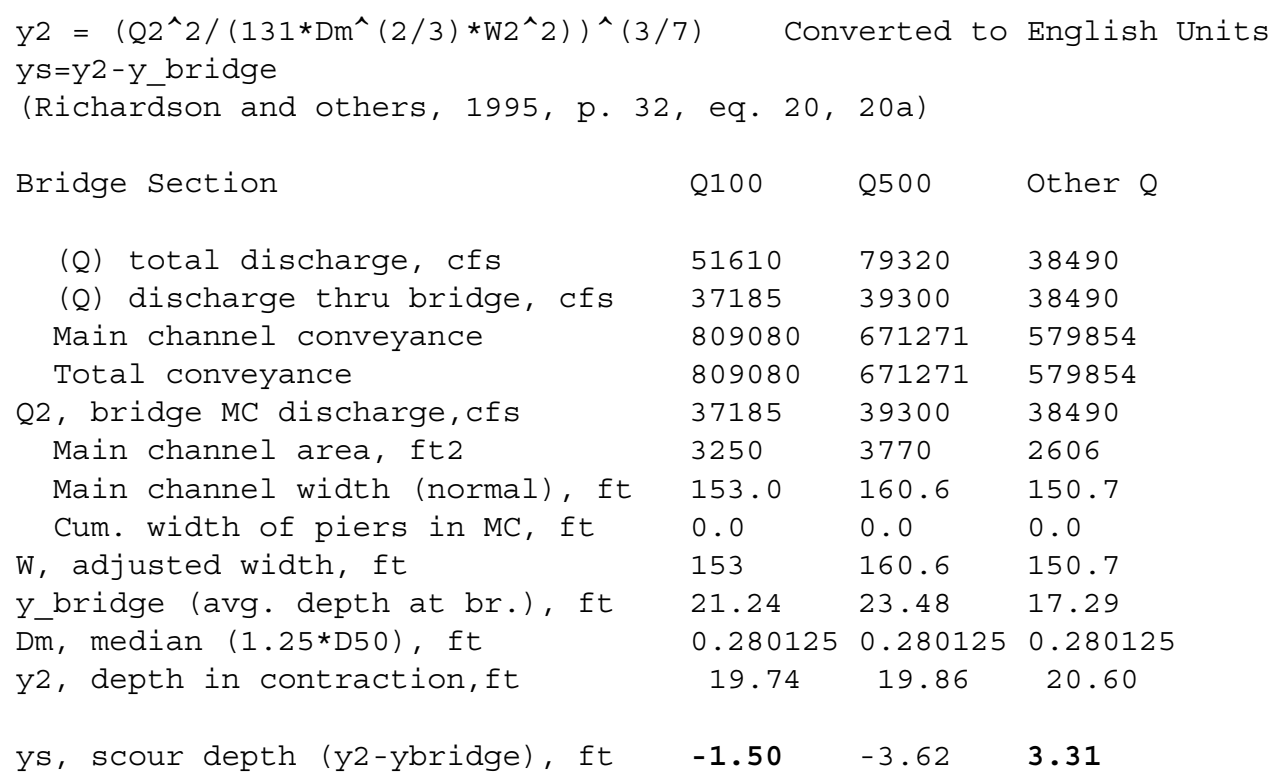

\begin{tabular}{|c|c|c|c|c|}
\hline \multicolumn{5}{|c|}{$\begin{array}{l}\text { Pressure Flow Scour (contraction scour for orifice f } \\
\text { Chang pressure flow equation } \quad \mathrm{Hb}+\mathrm{Ys}=\mathrm{Cq} q^{*} \mathrm{qbr} / \mathrm{VC}\end{array}$} \\
\hline \multicolumn{5}{|c|}{$\begin{array}{l}\mathrm{Cq}=1 / \mathrm{Cf} * \mathrm{CC} \quad \mathrm{Cf}=1.5 * \mathrm{Fr}^{\wedge} 0.43(<=1) \quad \mathrm{CC}=\mathrm{SQRT}[0.10(\mathrm{Hb} /(\mathrm{ya}-\mathrm{w})-0.56)]+0.79 \\
\text { Umbrell pressure flow equation } \\
(\mathrm{Hb}+\mathrm{Ys}) / \mathrm{ya}=1.1021 *[(1-\mathrm{w} / \mathrm{ya}) *(\mathrm{Va} / \mathrm{VC})]^{\wedge} 0.6031 \\
\text { (Richardson and other, 1995, p. 144-146) }\end{array}$} \\
\hline & Q100 & Q500 & OtherQ & \\
\hline Q, total, cfs & 51610 & 79320 & 38490 & \\
\hline Q, thru bridge $M C$, cfs & 37185 & 39300 & 38490 & \\
\hline Vc, critical velocity, ft/s & 10.98 & 11.27 & 10.65 & \\
\hline Va, velocity MC approach, ft/s & 8.56 & 9.27 & 9.41 & \\
\hline Main channel width (normal), ft & 153.0 & 160.6 & 150.7 & \\
\hline Cum. width of piers in MC, ft & 0.0 & 0.0 & 0.0 & \\
\hline w, adjusted width, ft & 153.0 & 160.6 & 150.7 & \\
\hline qbr, unit discharge, ft2/s & 243.0 & 244.7 & 255.4 & \\
\hline Area of full opening, ft2 & 3249.8 & 3770.4 & 2605.8 & \\
\hline Hb, depth of full opening, ft & 21.24 & 23.48 & 17.29 & \\
\hline Fr, Froude number, bridge MC & 0 & 0.38 & 0 & \\
\hline Cf, Fr correction factor $(<=1.0)$ & 0.00 & 0.99 & 0.00 & \\
\hline **Area at downstream face, ft2 & $\mathrm{N} / \mathrm{A}$ & $\mathrm{N} / \mathrm{A}$ & $\mathrm{N} / \mathrm{A}$ & \\
\hline
\end{tabular}




$\begin{array}{llll}* * \mathrm{Hb}, \text { depth at downstream face, ft } & \text { N/A } & \text { N/A } & \text { N/A } \\ * * \text { Fr, Froude number at DS face } & \text { ERR } & \text { ERR } & \text { ERR } \\ * * \text { Cf, for downstream face }(<=1.0) & \text { N/A } & \text { N/A } & \text { N/A } \\ \text { Elevation of Low Steel, ft } & 0 & 503.31 & 0 \\ \text { Elevation of Bed, ft } & -21.24 & 479.83 & -17.29 \\ \text { Elevation of Approach, ft } & 0 & 505.93 & 0 \\ \text { Friction loss, approach, ft } & 0 & 0.71 & 0 \\ \text { Elevation of WS immediately US, ft } & 0.00 & 505.22 & 0.00 \\ \text { ya, depth immediately US, ft } & 21.24 & 25.39 & 17.29 \\ \text { Mean elevation of deck, ft } & 0 & 507.18 & 0 \\ \text { w, depth of overflow, ft (>=0) } & 0.00 & 0.00 & 0.00 \\ \text { Cc, vert contrac correction (<=1.0) } & 1.00 & 0.98 & 1.00 \\ * * C C, \text { for downstream face (<=1.0) } & \text { ERR } & 0.79 & \text { ERR } \\ \text { Ys, scour w/Chang equation, ft } & \text { N/A } & -1.12 & \text { N/A } \\ \text { Ys, scour w/Umbrell equation, ft } & \text { N/A } & 1.39 & \text { N/A }\end{array}$

Armoring

$\mathrm{DC}=\left[\left(1.94 * \mathrm{~V}^{\wedge} 2\right) /(5.75 * \log (12.27 * \mathrm{y} / \mathrm{D} 90))^{\wedge} 2\right] /[0.03 *(165-62.4)]$

Depth to Armoring $=3 *(1 / \mathrm{PC}-1)$

(Federal Highway Administration, 1993)

$\begin{array}{llll}\text { Downstream bridge face property } & \begin{array}{l}100-\mathrm{yr} \\ \text { Q, discharge thru bridge MC, cfs } \\ 37185\end{array} & 3900 \mathrm{yr} & \text { Other Q } \\ \text { Main channel area (DS), ft2 } & 3249.8 & 3770.4 & 2605.8 \\ \text { Main channel width (normal), ft } & 153.0 & 160.6 & 150.7 \\ \text { Cum. width of piers, ft } & 0.0 & 0.0 & 0.0 \\ \text { Adj. main channel width, ft } & 153.0 & 160.6 & 150.7 \\ \text { D90, ft } & 0.4732 & 0.4732 & 0.4732 \\ \text { D95, ft } & 0.5880 & 0.5880 & 0.5880 \\ \text { DC, critical grain size, ft } & 0.3322 & 0.2671 & 0.5915 \\ \text { Pc, Decimal percent coarser than Dc } & 0.264 & 0.394 & 0.049\end{array}$

$\begin{array}{llll}\text { Depth to armoring, ft } & 2.77 & 1.23 & \text { N/A }\end{array}$

Abutment Scour

Froehlich's Abutment Scour

$\mathrm{Ys} / \mathrm{Y} 1=2.27 * \mathrm{~K} 1 * \mathrm{~K} 2 *\left(\mathrm{a}^{\prime} / \mathrm{Y} 1\right)^{\wedge} 0.43 * \mathrm{Fr} 1^{\wedge} 0.61+1$

(Richardson and others, 1995, p. 48, eq. 28)

\begin{tabular}{|c|c|c|c|c|c|c|}
\hline \multirow[b]{2}{*}{ Characteristic } & \multicolumn{2}{|c|}{ Left Abutment } & \multicolumn{4}{|c|}{ Right Abutment } \\
\hline & 100 yr 0 & 500 yr & Other Q & $100 \mathrm{yr}$ & 500 yr & Other Q \\
\hline (Qt), total discharge, cfs & 51610 & 79320 & 38490 & 51610 & 79320 & 38490 \\
\hline a', abut.length blocking flow, ft & 160.6 & 179.7 & 60.8 & 809.4 & 827.5 & 211 \\
\hline Ae, area of blocked flow ft 2 & 872.32 & 1158.59 & 615.15 & 2203.36 & 2844.49 & 1450.07 \\
\hline $\begin{array}{l}\text { Qe, discharge blocked abut., cfs } \\
\text { (If using Qtotal_overbank to obt }\end{array}$ & $\begin{array}{r}5367.99 \\
\text { ain Ve, }\end{array}$ & eave $\overline{-}$ Qe & $\begin{array}{r}4447.47 \\
\text { lank and }\end{array}$ & $\begin{array}{c}-- \\
\text { enter } \mathrm{Ve}\end{array}$ & and $\mathrm{Fr} \mathrm{r}$ & $\begin{array}{r}6888.72 \\
\text { anually) }\end{array}$ \\
\hline Ve, $(\mathrm{Qe} / \mathrm{Ae}), \mathrm{ft} / \mathrm{s}$ & 6.15 & 6.05 & 7.23 & 4.15 & 5.25 & 4.75 \\
\hline ya, depth of $f / p$ flow, ft & 5.43 & 6.45 & 10.12 & 2.72 & 3.44 & 6.87 \\
\hline $\begin{array}{l}\text {--Coeff., K1, for abut. type (1.0, } \\
\text { K1 }\end{array}$ & $\begin{array}{c}\text { ver } \\
1\end{array}$ & $\begin{array}{c}0.82 \text { ， } \\
1\end{array}$ & i. w/ & $\begin{array}{l}\text { 19wall } ; \\
0.82\end{array}$ & $\begin{array}{l}.55, \mathrm{sp} \\
0.82\end{array}$ & 0.82 \\
\hline
\end{tabular}




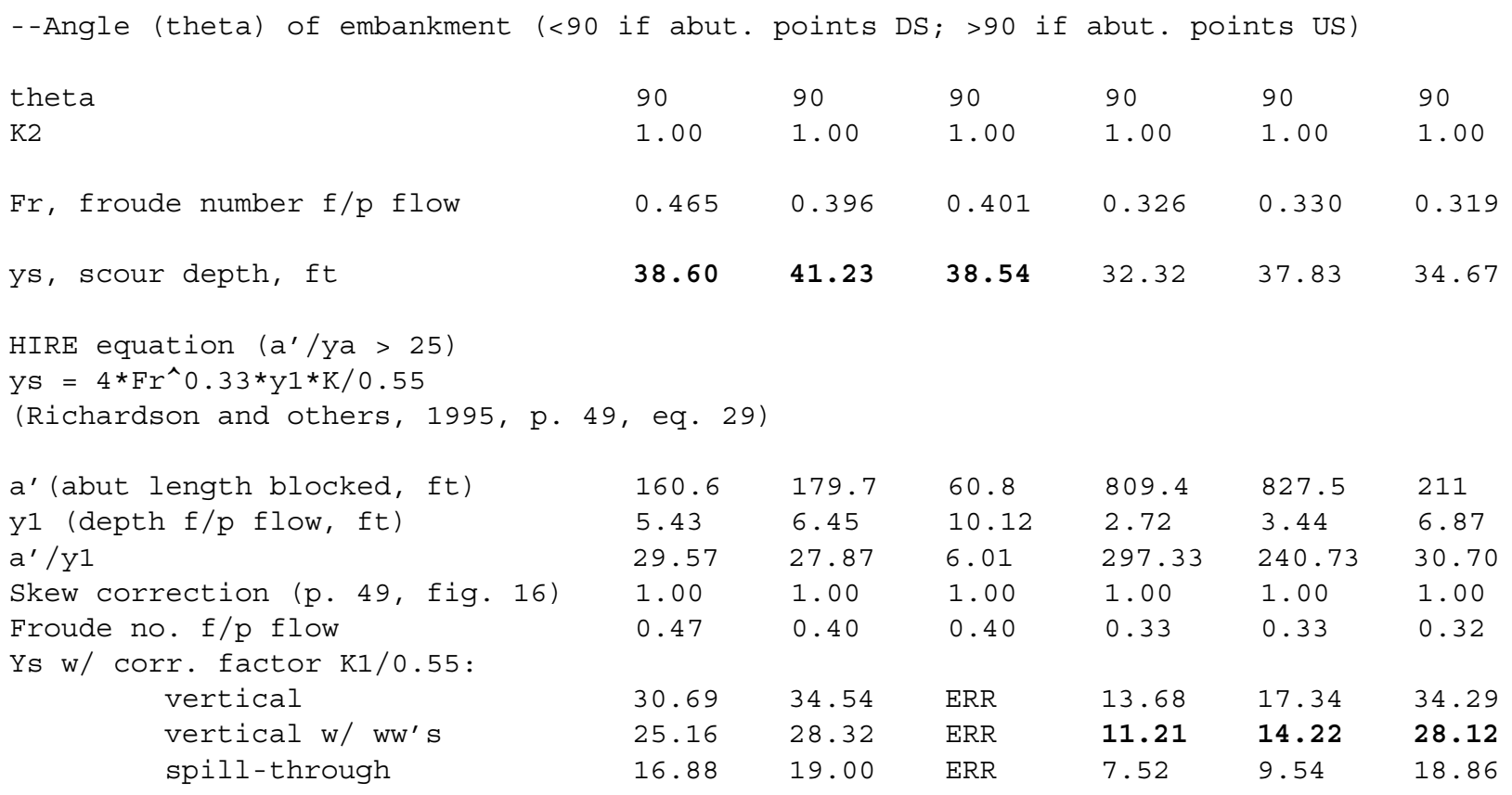

Abutment riprap Sizing

Isbash Relationship

$\mathrm{D} 50=\mathrm{Y} * \mathrm{~K} * \mathrm{Fr} \wedge 2 /(\mathrm{SS}-1)$ and $\mathrm{D} 50=\mathrm{Y} * \mathrm{~K} *\left(\mathrm{Fr} \mathrm{F}^{\wedge}\right)^{\wedge} 0.14 /(\mathrm{SS}-1)$

(Richardson and others, 1995, p112, eq. 81,82)

\begin{tabular}{|c|c|c|c|c|c|c|}
\hline Characteristic & Q100 & 2500 & Other Q & Q100 & Q500 & Other $Q$ \\
\hline Fr, Froude Number & 0.54 & 0.38 & 0.69 & 0.54 & 0.38 & 0.69 \\
\hline y, depth of flow in bridge, ft & 21.24 & 23.48 & 17.29 & 21.24 & 23.48 & 17.29 \\
\hline $\begin{array}{l}\text { ledian stone Diameter for riprap } \\
\text { Fr }<=0.8 \text { (vertical abut.) }\end{array}$ & $\begin{array}{l}: \text { left } \\
3.83\end{array}$ & $\begin{array}{l}\text { atment } \\
2.10\end{array}$ & 5.09 & $\begin{array}{l}\text { right } \\
3.83\end{array}$ & $\begin{array}{l}\text { abutment } \\
2.10\end{array}$ & $\begin{array}{l}\text { ft } \\
5.09\end{array}$ \\
\hline Fr>0.8 (vertical abut.) & ERR & ERR & ERR & ERR & ERR & ERR \\
\hline
\end{tabular}


